\title{
Natural killer cell-based immunotherapy for acute myeloid leukemia
}

\author{
Jing Xu and Ting $\mathrm{Niu}^{*}$ (1)
}

\begin{abstract}
Despite considerable progress has been achieved in the treatment of acute myeloid leukemia over the past decades, relapse remains a major problem. Novel therapeutic options aimed at attaining minimal residual disease-negative complete remission are expected to reduce the incidence of relapse and prolong survival. Natural killer cell-based immunotherapy is put forward as an option to tackle the unmet clinical needs. There have been an increasing number of therapeutic dimensions ranging from adoptive NK cell transfer, chimeric antigen receptor-modified NK cells, antibodies, cytokines to immunomodulatory drugs. In this review, we will summarize different forms of NK cell-based immunotherapy for AML based on preclinical investigations and clinical trials.
\end{abstract}

Keywords: Acute myeloid leukemia, Natural killer cells, Immunotherapy, Adoptive NK cell transfer, Chimeric antigen receptor-modified NK cells, Antibodies, Cytokines

\section{Background}

Acute myeloid leukemia (AML) is a clinically and genetically heterogeneous disease with unsatisfactory outcomes. Over the last few years, considerable progress has been achieved in the treatment of AML with the development and implementation of new drugs [1, 2]. However, allogeneic hematopoietic cell transplantation (HCT) has been recognized as the only way to cure AML so far and relapse remains a major problem. Novel therapeutic options aimed at attaining minimal residual disease (MRD)-negative complete remission (CR) are expected to reduce the incidence of relapse and prolong survival. Thus, immunotherapy becomes an option to tackle unmet clinical needs in AML $[3,4]$.

Immunotherapy has been recognized as an incredibly promising therapeutic strategy for numerous cancers [5]. The adoption of this treatment modality is based on mechanisms of immune surveillance/response and cancer escape [6]. Under physiological conditions, immune

\footnotetext{
*Correspondence: tingniu@sina.com
}

Department of Hematology, West China Hospital, Sichuan University,

Chengdu 610041, China cells and substances in the immune system play pivotal roles in detecting and destroying pathogen-infected or neoplastically transformed cells. But they become less potent in cancer elimination when malignant cells display the loss of antigenicity and/or immunogenicity and are surrounded by an immunosuppressive microenvironment [6]. Thus, immunotherapy with strategies of reboosting patients' own immune system or initiating new immune response to fight cancers has been demonstrated with the capacity of producing sustainable clinical benefits against both solid and hematological malignancies [7-9].

Natural killer (NK) cell-based immunotherapy represents one of the novel immunotherapeutic strategies recently, unleashing immune suppression of NK cells to attack various cancers [10-12]. With the progressive elucidation of NK cell immunobiology and the development of manipulative techniques, the field of NK cellbased immunotherapy in hematological malignancies has been expanding and accelerating over the past years, including adoptive NK cell transfer [13-16], chimeric antigen receptor (CAR)-modified NK cells [17-22], antibodies [23-25], cytokines [26, 27] and drug treatment [28-31]. Despite remarkable progress has been made, original author(s) and the source, provide a link to the Creative Commons licence, and indicate if changes were made. The images or other third party material in this article are included in the article's Creative Commons licence, unless indicated otherwise in a credit line to the material. If material is not included in the article's Creative Commons licence and your intended use is not permitted by statutory regulation or exceeds the permitted use, you will need to obtain permission directly from the copyright holder. To view a copy of this licence, visit http://creativecommons.org/licenses/by/4.0/. The Creative Commons Public Domain Dedication waiver (http://creativeco mmons.org/publicdomain/zero/1.0/) applies to the data made available in this article, unless otherwise stated in a credit line to the data. 
the application in AML is still at the initial stage. Firstly, clinical trials with results showing the efficacy and safety of these therapeutic approaches are limited, most of which are currently still in progress. Secondly, preclinical studies of NK cell-based immunotherapy are constantly emerging, in the aspect of new methodologies to utilize NK cells and strategies to enhance the response [32, 33].

Herein, in this review, we provide an overview of NK cell biology, the pathology of NK cells in AML and the recent advances in NK cell-based immunotherapy for AML based on preclinical investigations and clinical trials.

\section{Biology of NK cells}

NK cells belong to innate lymphoid cells that contribute to immune system's first-line defense against infections and malignant diseases [34]. They can be categorized into two subsets on the basis of surface expression levels of CD56 and CD16, as measured by the intensity of immunofluorescence. The canonical $\mathrm{CD} 56{ }^{\mathrm{dim}} \mathrm{CD} 16^{+}$ NK cell subset comprises around $90 \%$ of the total population in peripheral blood and exerts strong cytolytic activity through releasing cytotoxic granules containing perforin and granzymes. The rest $10 \%$ of NK cell population, known as $\mathrm{CD} 56^{\text {bright }} \mathrm{CD} 16^{-}$, is a potent producer of immunoregulatory cytokines including interferon
(IFN)- $\gamma$, tumor necrosis factor (TNF)- $\alpha / \beta$ and interleukin (IL) -10 [35].

The cytotoxic function of NK cells is finely regulated by a complex array of surface inhibitory receptors [e.g., inhibitory killer immunoglobulin-like receptors (KIRs), leukocyte immunoglobulin-like receptors (LIRs) and CD94/natural killer group 2A (NKG2A)] and activating receptors [e.g., activating KIRs, CD94/NKG2C, NKG2D and natural cytotoxicity receptors (NCRs)] that deliver suppressive and stimulatory signals, respectively (Fig. 1) $[36,37]$. In line with the diversity of major histocompatibility complex (MHC) molecules in populations, KIRs are genetically determined and display a high level of polymorphism. There are two main groups of KIR haplotypes, termed as "A" and "B", as classified by the distinct gene content. KIR A haplotypes mainly contain inhibitory KIR genes and only one activating KIR gene KIR2DS4, whereas KIR B haplotypes carry, besides inhibitory KIR genes, various numbers and combinations of activating KIR genes [38, 39]. The considerable differences of both allelic polymorphism and KIR gene content account for the high variability of KIR gene family among different individuals.

NK cell-mediated cytotoxicity is based on the notion of "missing self-recognition" and "induced self-recognition” [40]. During NK cell development, inhibitory KIR receptors encounter with MHC class I (MHC-I) ligands

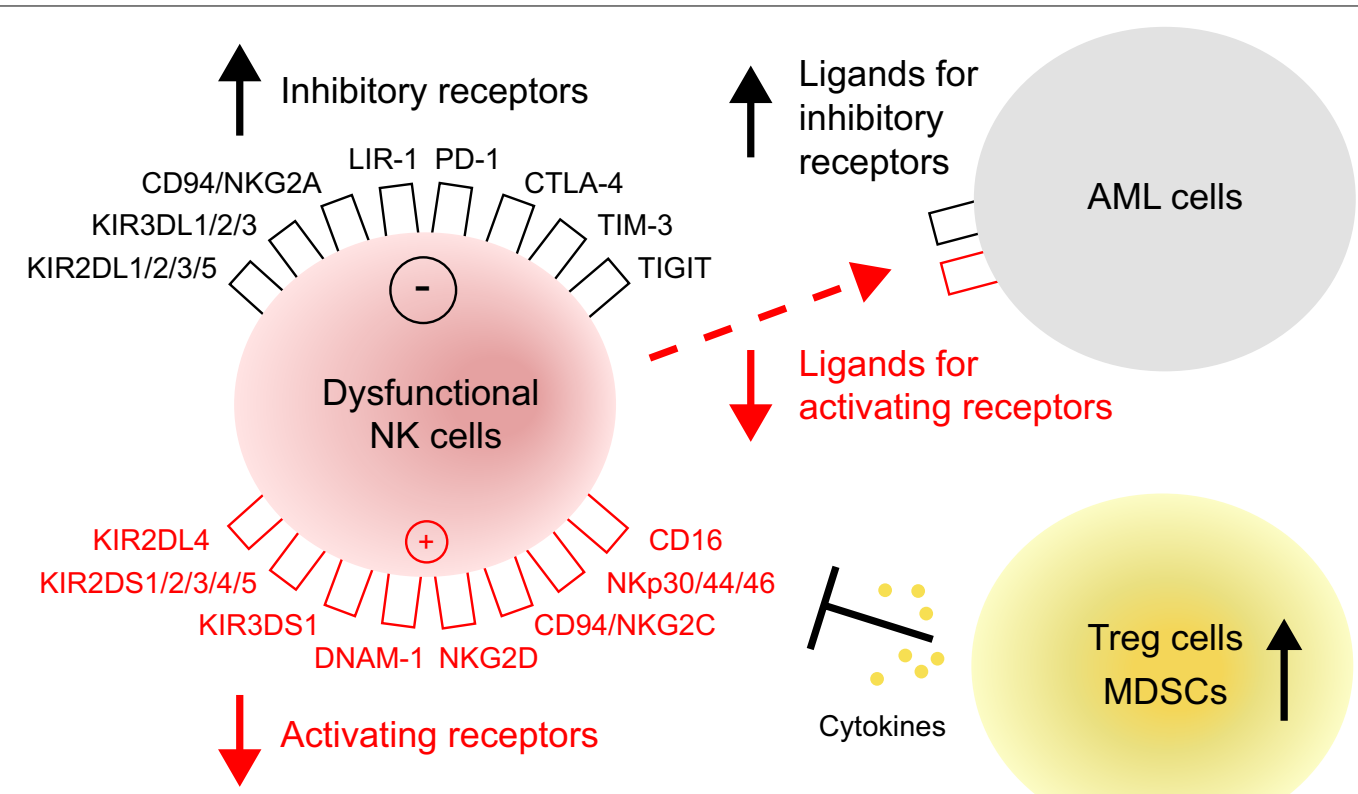

Fig. 1 Mechanisms of immune escape from NK cell-mediated recognition in AML. Dysfunctional NK cells exhibit an imbalanced receptor expression with the overexpression of inhibitory receptors and the underexpression of activating receptors. AML cells display a defective expression of cognate ligands for NK cell activating and inhibitory receptors. The tumor microenvironment consisting of Treg cells and MDSCs can interfere with the function of NK cells through the secreting of cytokines. MDSC myeloid-derived suppressor cell, NK natural killer cell; Treg regulatory T cell 
on their own hematopoietic cells, leading to the acquisition of functional competence and self-tolerance [41, 42]. Both the reduction/absence of MHC-I molecules and the upregulation/de novo expression of ligands for activating receptors on tumor cells can elicit NK cell immune response against "non-self," through releasing cytotoxic granules, secreting cytokines and inducing death receptor-dependent apoptosis [36, 43]. Apart from the direct receptor-based recognition between NK cells and tumor cells that potentiates the anti-tumor function of NK cells, they can kill tumor cells by antibody-dependent cellmediated cytotoxicity (ADCC) as well, which is mediated by the IgG Fc receptor CD16 [44].

In addition, the activation of NK cells can be induced by other immune cells such as macrophages and dendritic cells (DCs) as well, either through direct cell-to-cell contacts or the release of cytokines such as IL-12, IL-15, IL-18 and IFN- $\alpha / \beta$, promoting NK cell cytotoxicity and IFN- $\gamma$ production $[45,46]$.

\section{Dysfunction of NK cell-mediated anti-leukemia responses in patients with AML}

In AML, leukemia cells can escape from NK cell-mediated recognition as a consequence of NK cell abnormalities, immunosuppressive properties of AML cells or interactions between NK cells and other immune cells in favor of immune escape (Fig. 1) [47].

Since the function of NK cells is tightly regulated by their sophisticated repertoire of inhibitory and activating receptors, imbalanced receptor expressions can lead to NK cell dysfunction. Studies evaluating the expression of these molecular receptors on NK cells showed the underexpression of activating receptors such as NKG2D, NCRs and DNAX accessory molecule-1 (DNAM-1) as well as overexpression of inhibitory receptors such as KIR2DL2/ L3 and NKG2A in AML patients as compared with healthy controls [48-52]. Direct contact between AML cells and NK cells, high expression of CD200 on AML cells, soluble NKG2D ligands (NKG2DLs) in the sera and suppressive tumor microenvironment are factors that lead to defective receptor expression changes [49, 53, 54].

In addition to NK cell abnormalities, leukemia cells themselves displaying a defective expression of ligands for NK cell activating/inhibitory receptors give rise to the attenuation of NK cell-mediated anti-leukemia responses as well. For instance, the low expression of NKG2DLs [MHC class I chain-related proteins (MIC) and UL16binding proteins (ULBP)], NCR ligands and DNAM-1 ligands (CD112 and CD155) on AML cells can render them resistant to NK cell killing $[55,56]$. The deficient NKG2DL expression on AML cells may be caused by aberrant epigenetic mechanisms or the release of soluble forms from the cell surface by metalloproteinases [57,
58]. Whereas, upregulation of inhibitory immune checkpoint molecules programmed cell death ligand-1 (PD-L1) and PD-L2 is observed in AML blasts [59].

The tumor microenvironment, which possesses immunosuppressive cells, such as regulatory $\mathrm{T}$ cells (Tregs), myeloid-derived suppressor cells (MDSCs), tumor-associated macrophages (TAMs) and tolerogenic DCs as well as immunosuppressive factors such as transforming growth factor (TGF)- $\beta$, IL-10 and indoleamine 2,3 dioxygenase (IDO), is another major limitation to the effectiveness of NK cells in AML [60, 61].

It is worth noting that expressions of NK receptors and their cognate ligands on leukemic cells as well as the signals deriving from tumor microenvironment are deemed to impact clinical outcomes and relapse in AML patients [47]. These NK cell function-related adverse prognostic parameters including hypomaturation NK cell profile $\left(\mathrm{CD} 56^{\text {bright }}\right.$ and $\left.\mathrm{KIR}^{-} / \mathrm{CD} 57^{-}\right)$, increased NKG2A and decreased NCR on NK cells, increased CD200 and decreased ULBP1 on AML cells $[49,51,53$, 62-66]. Moreover, persistence of dysfunctional NK cells was found even in patients who achieve first CR after intensive chemotherapy [67]. Thus, the presence of dysfunctional NK cells in AML and their prognostic relevance provide the rationale for the use of NK cell-based immunotherapy to restore impaired NK cell cytotoxicity against AML.

\section{NK cell-based immunotherapy in AML Adoptive NK cell transfer}

The strategy of adoptive NK cell transfer was put forward based on beneficial effects of NK cell alloreactivity in the setting of allogeneic HCT (allo-HCT). NK cell alloreactivity is triggered by the mismatch between KIRs on donor NK cells and human leukocyte antigen (HLA) class I molecules on recipient cells, the effectiveness of which in leukemia was initially described by Perugia group [68, 69]. Alloreactions mediated by donor NK cells can kill leukemia through graft-versus-leukemia $(\mathrm{GvL})$ effect, promote engraftment through ablation of recipient $\mathrm{T}$ cells and protect against graft-versus-host disease (GvHD) through depleting recipient antigen-presenting cells and producing IL-10 [70, 71]. Transplantation from NK alloreactive donors is considered as a strong independent factor predicting survival in allo-HCT recipients, especially from donors with more KIR B genecontent motifs [72-75]. Besides, rapid NK cell recovery post-HCT is associated with improved outcomes, while impaired NK function may be the cause of relapse [7679]. Taken together, given the basic notions of NK cell alloreactivity and the prognostic effects of functional NK cell counts, adoptive transfer of NK cells for the 
management of AML has been explored in clinical applications (Fig. 2a).

Despite HCT has yielded a high rate of curability for AML, it is associated with transplant-related morbidity and mortality. Besides, not every patient is a candidate for HCT and relapse after HCT remains the most frequent cause of treatment failure. Therefore, adoptive NK cell transfer seems to be an ideal option as adjuvant and alternative treatment, and it has already been performed in the context of HCT as well as in the non-HCT setting.

\section{Adoptive NK cell transfer in the context of HCT}

Donor-derived NK cells are most commonly obtained from donor leukapheresis products using a magnetic cell sorting (MACS) system by $\mathrm{CD} 3$ depletion with or without CD56 enrichment [80-84]. They can also be generated by ex vivo differentiation from donor CD34+hematopoietic progenitor cells [85]. NK cell transfer after HLA-haploidentical HCT is well tolerated and consolidates engraftment [80, 86]. Remarkably, a phase I study investigating the clinical effect of IL-15 plus IL-21 stimulated CD3-depleted NK cells given 2 and 3 weeks after HCT demonstrated that leukemia progression reduced compared with historical patients who have undergone HCT after the same conditioning regimen without NK cell infusion (hazard ratio 0.527, $p=0.042$ ) [81]. Another phase I study showed that multiple doses of NK cells (days-2, 7 and 28 post-HCT) expanded ex vivo with K562-mbIL21-41BBL feeder cells, which were genetically modified K562 leukemia cell line expressing membrane-bound IL-21 and the 41BB ligand, could be effective in controlling leukemia relapse as well [82]. However, another study showed that compared with NK cell transfer at weeks 2 and 3 post-HCT, additional early transfer (days 6 and 9 post-HCT) was associated with significant cytokine release syndrome (CRS)-related toxicity and was not associated with less leukemia progression in patients with relapsed/refractory (R/R) AML [83].

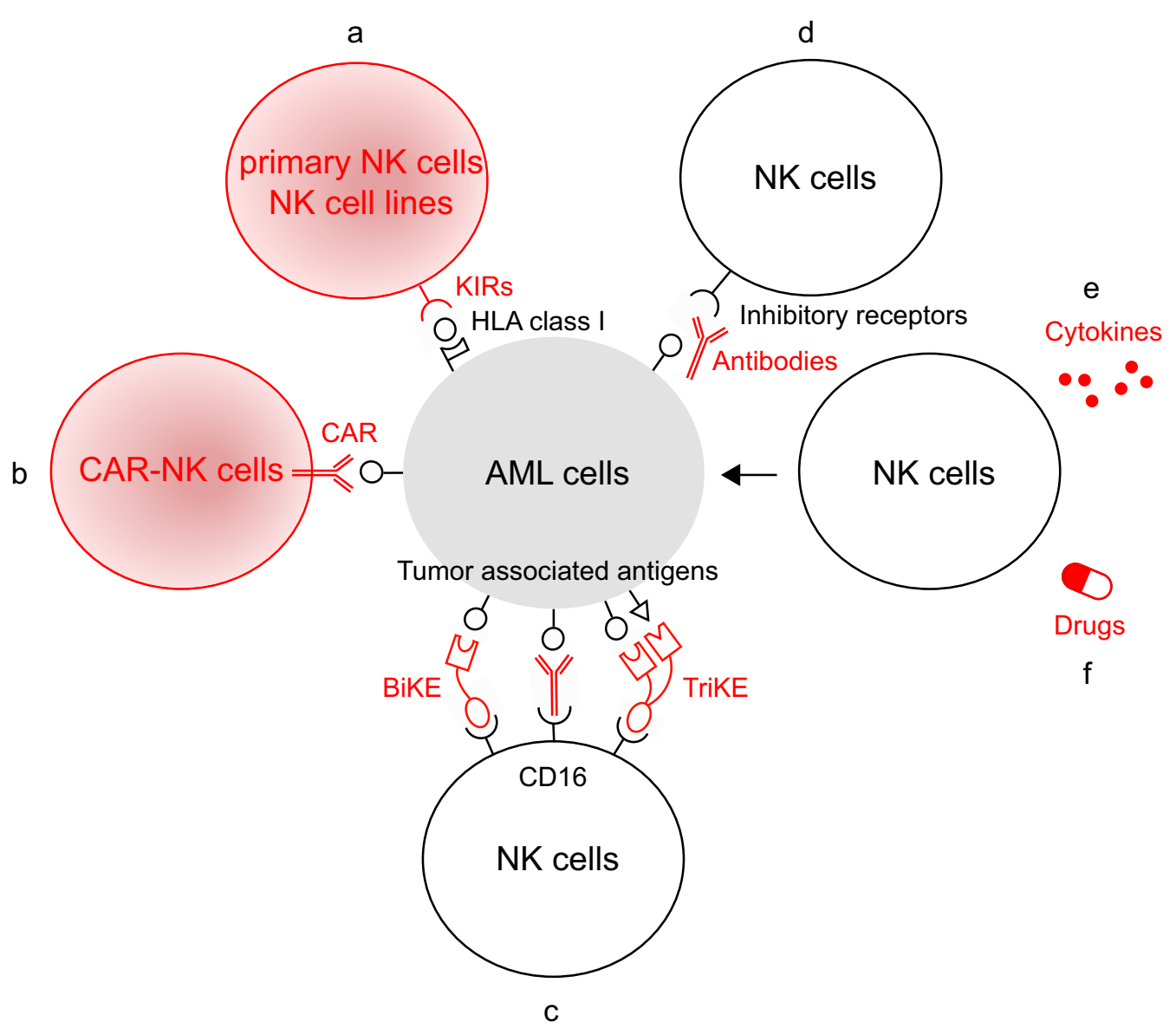

Fig. 2 Strategies of NK cell-based immunotherapy in activating the reconstitution of NK cells against AML. a Adoptive NK cell transfer. b CAR-NK cell therapy. c Antibodies targeting tumor associated antigens, BiKE and TrikE. $\mathbf{d}$ Antibodies targeting NK cell inhibitory receptors. e Cytokines. $\mathbf{f}$ Drugs with immunomodulatory function. BiKE bi-specific killer cell engager, CAR chimeric antigen receptor, HLA human leukocyte antigen, KIR killer immunoglobulin-like receptor, TriKE tri-specific killer cell engager 
Notably, high expression of NKp30 on donor NK cells was an independent predictor of high CR and low leukemia progression [83].

In addition, NK cells are also safe and feasible to be infused prior to HCT. A phase I study infusing escalating doses of donor-derived NK cells as a component of the preparative regimen for allo-HCT (day- 8 preHCT) demonstrated that relapse-free survival was highly associated with the number of NK cells delivered [87]. Besides, NK cell transfer can also be applied as a bridge to $\mathrm{HCT}$ in R/R AML, which is useful in the reduction in disease burden to make patients eligible to proceed to HCT [84].

\section{Adoptive NK cell transfer in the non-HCT setting}

Since the limitations of HCT make it not applicable to all patients, it is conceivable to propel the development of adoptive NK cell transfer outside the transplantation setting.

Miller et al. was the first to conduct NK cell transfer in adult AML patients without prior HCT, reporting that haploidentical NK cell transfer with the intense high-dose cyclophosphamide and fludarabine immune suppression regimen, CD3 depletion and IL-2 administration both ex vivo and in vivo was a safe treatment with successful NK cell proliferation and activation in R/R AML (CR 5/19) [88]. Over the years, modifications to this approach have led to remarkable progress, ranging from donor selection according to KIR-ligand mismatch to improve outcomes, NK cell purification using CD3 depletion followed by CD56 enrichment to avoid side effects caused by residual cells, to milder conditioning regimens and lower dose of IL-2 in vivo to make it a well-tolerated regimen. Adoptive NK cell transfer is a feasible strategy for AML not only to induce remission, but also to maintain CR [89-93]. The combination of consolidation therapies of NK cell transfer and chemotherapy contributed to the further remission with decreased MRD and the reduction in long-term recurrence in AML patients at CR [94]. Though a phase II trial reported that NK cell transfer as a consolidation therapy for pediatric AML in first CR did not decrease relapse and increase overall survival (OS), the result of another just concluded phase II trial (NCT02763475) with a higher number of NK cell administration is worth the wait $[95,96]$.

Since the higher number of donor alloreactive NK cells correlates with better outcomes, ex vivo generation and in vivo expansion of an adequate number of donor NK cells with robust anti-leukemia potential are highly warranted [92]. In terms of ex vivo manipulating methods, Miller et al. demonstrated the superiority of CD3 and CD19 depletion method compared with CD3 depletion alone and CD3 depletion followed by CD56 enrichment methods, with no cause of negative effects by co-infused monocytes [97]. NK cell expansion and functional activity can be significantly enhanced by co-culturing donor's peripheral blood mononuclear cells (PBMC) with cytokines (mainly IL-2 and IL-15) or feeder cells bearing membrane-bound cytokines (such as K562-mbIL1541BBL or K562-mbIL21-41BBL) [94, 98-100]. The feeder-free approach of using plasma membrane particles derived from K562-mbIL15-41BBL feeder cells resulted in great expansion of NK cells as well and avoided tumorderived feeder cells being injected into patients [101]. Two phase I studies demonstrated NK cells primed with the lysate of CTV-1 leukemia cell line could prolong CR in high-risk AML patients [102, 103]. Despite IL-2 has the effect of stimulating NK cells, it stimulates host Treg cells in the meanwhile, which can inhibit NK cell proliferation and expansion in vivo. IL-15 was proposed as an alternative to IL-2 without such drawback [104, 105]. The first-in-human trial of using in vivo recombinant human IL-15 to potentiate haploidentical NK cell transfer in R/R AML showed better rates of NK cell expansion and remission compared with previous trials with IL-2, but CRS was observed when IL-15 was administered subcutaneously [106]. Furthermore, Miller et al. proposed a method of incorporating Treg depletion with IL-2 diphtheria toxin (IL2DT) into adoptive transfer platform. IL2DT was delivered to patients 1 or 2 days before NK cell transfer and it improved CR rate $(53 \%$ versus $21 \% ; P=0.02)$ and disease-free survival (33\% versus $5 \%$; $P<0.01)$ for $\mathrm{R} / \mathrm{R}$ AML patients [97]. It was showed that the use of IL2DT or low-dose irradiation as part of conditioning resulted in increased NK cell homing and persistence in the bone marrow, which correlated with better leukemia control [107].

Apart from quantity demands for NK cells, alternative sources for NK cells can facilitate their clinical applications as well. A phase I clinical trial evaluated the feasibility and safety of transferring activated human NK-92 cell lines to patients with R/R AML. NK-92 cells possess advantages of easy cultivation and expansion and can be repeatedly infused in the context of lymphodepletion [108]. Its derivative cell line NK-92MI without the presence of surface sialic acid-binding immunoglobulin-like lectins (siglec)-7 exhibited high and sustainable cytotoxicity against NK-92MI-resistant leukemia cells [109]. Besides, a study established the proof-of-concept of the feasibility of NK cells generated from CD34+hematopoietic stem and progenitor cells (HSPC) isolated from cryopreserved umbilical cord blood (UCB) in a preclinical AML xenograft model [110]. The first-in-human study exploiting UCB-derived HSPC-NK cells in the treatment of elderly AML patients in morphologic CR found NK cell expansion and further maturation in vivo 
as well as a reduction in MRD without the induction of NK cell-related toxicity [111]. Another study evaluating placental-derived HSPC-NK cells (PNK-007) in R/R AML demonstrated an encouraging safety profile, but larger scale studies are needed to assess clinical outcomes [112]. A clinical trial investigating the feasibility of CYNK-001, the cryopreserved successor product to PNK-007, has recently been initiated (NCT04310592). Moreover, FT516, a NK cell product derived from a clonal master engineered induced pluripotent stem cell (iPSC) line, as a monotherapy for $\mathrm{R} / \mathrm{R} \mathrm{AML}$ is in clinical investigation (NCT04023071). These "off-the-shelf" products have significant benefits over primary NK cells from adult donors in the aspect of low costs, high therapeutic dosages, immediately application, choosing appropriate KIR B haplotype alloreactive donors and doing genetic modifications.

Further clinical trials are underway to evaluate the safety and efficacy of adoptive NK cell transfer, with the exploration of optimal NK cell dosages and resources, the optimal time points in relation to $\mathrm{HCT}$ and potential combination therapies. A list of currently ongoing clinical trials of NK cell transfer is provided in Table 1.

\section{CAR-NK cell therapy}

In adoptive NK cell transfer, the ability of NK cells to mount an immune response against AML cells is largely dependent on the interactions between NK cell activating/inhibitory receptors with their cognate ligands on target cells. In order to augment the specificity and cytotoxicity, genetically modified NK cells such as CAR-modified-NK cells are designed (Fig. 2b). Since the success of CAR-T therapy in the treatment of B-lineage acute lymphoblastic leukemia and B-cell lymphoma has not yet been translated into the treatment of AML and its wide applications are limited by adverse effects such as CRS $[113,114]$, NK cells with short lifespan are being considered as promising alternatives to modified $\mathrm{T}$ cells with favorable toxicity profiles and low manufacturing costs [115]. Nowadays, the actions of CAR-NK cells are being extensively studied in a variety of tumor models, but the applications in AML are relatively limited and mainly at the preclinical stage.

The optimal choice of leukemia specific markers that can be targeted by CAR-NK cells is a major obstacle, since AML shares some phenotypic markers with normal hematopoietic stem cells (HSCs). Myeloid differentiation antigen CD33 is detected on blasts of $>85 \%$ of $\mathrm{AML}$ patients and also on leukemia stem cells (LSCs) [116]. A preclinical investigation ascertained the targeting effect of NK cell line YT with gene transfer of a CD33-specific immunoglobulin-based humanized chimeric $\mathrm{T}$ cell receptor (cIgTCR) to CD33+AML cell lines [117]. The first-in-man reported phase I trial of CAR-NK cells demonstrated the safety of irradiated CD33-CD28-4-1BBCD3 CAR-NK-92 cells infusion in 3 patients with $R / R$ AML, but it did not demonstrate obvious clinical efficacy [118]. Larger-scale clinical trials are warranted to determine the effects (NCT02944162). CD4 is another antigen present on AML blasts without ubiquitous expression on HSPCs and non-hematopoietic cells. Salman et al. established the role of CD4-CD28-4-1BB-CD3 $\zeta$ CARNK-92 cells in robustly eliminating CD4+AML cells ex vivo and in mouse xenografts [119]. CD7 is detected in approximately $30 \%$ of AML cases and also presents as an attractive target $[120,121]$. CD7-CD28-4-1BB-CD3 $\zeta$ CAR-NK-92MI cells have significantly improved killing efficiency against CD7 + AML cells as compared with NK-92MI cells without genetic modifications, which provides a basis for clinical investigation (NCT02742727) [122].

As for the sources of CAR-NK cells, a preclinical study showed that CD123-CAR-NK-92 cell lines represented better CAR effector cells than primary human donor CD123-CAR-NK cells in terms of cytotoxic activities [123].

The lessons learned from CAR-T and CAR-NK cells in the treatment of other cancers are worthy to be exploited in CAR-NK cell therapy in AML in the future, including optimizing targets and structures of CAR-NK cells as well as investigating the ideal patient populations for this type of immunotherapy.

\section{Antibodies}

In the normal physiologic setting, the interaction of receptors-ligands and the process of ADCC are involved in the NK cell activation. Taking advantage of this functionality, monoclonal antibodies become another method of boosting patients' NK cells against AML. On the one hand, antibodies targeting tumor-associated antigens endow NK cells with the power of activation via ADCC effects. On the other hand, antibodies targeting NK cell inhibitory receptors have the potential to weaken inhibitory signals and let activating signals dominate the process. Great progress has been made in the field of antibody therapies, and the overview of ongoing clinical trials concerning novel antibodies for AML is presented in Table 2.

\section{Antibodies targeting tumor-associated antigens}

Antibodies targeting tumor-associated antigens are attractive means of immunotherapy for cancers, the mechanisms of which are in great part the induction of ADCC via NK cells (Fig. 2c). The outcomes of unconjugated antibodies were generally poor when used alone [124-126]. The effects could be enhanced by engineering 
Table 1 Overview of ongoing clinical trials of adoptive NK cell transfer in AML

\begin{tabular}{|c|c|c|c|c|c|}
\hline Identifier & Phase & Indication & In vivo cytokine & Transplantation & Outcome measure \\
\hline \multicolumn{6}{|c|}{ PBMC-derived NK cell infusion } \\
\hline NCT04221971 & 1 & R/R AML & None & No & $\begin{array}{l}\mathrm{AE} \text {, response, } \mathrm{NK} \text { cell metabolism, } \\
\text { migration and reconstruction, } \\
\text { cell count recovery, relapse }\end{array}$ \\
\hline NCT04220684 & । & R/R AML or MDS & None & No & $\begin{array}{l}\text { MTD, } A E \text {, response, survival, cell } \\
\text { count recovery, number of } \\
\text { patients able to proceed to } \mathrm{HCT}\end{array}$ \\
\hline NCT04209712 & । & AML with MRD & $\mathrm{IL}-2$ & No & $\mathrm{MRD}, \mathrm{AE}$ \\
\hline NCT02890758 & । & AML, MDS, et al & ALT-803 & No & $\begin{array}{l}\text { AE, response, survival, in vivo NK } \\
\text { level }\end{array}$ \\
\hline $\begin{array}{l}\text { NCT01787474 } \\
\text { NCT02809092 }\end{array}$ & $|/| \mid$ & R/R AML & None & No & MTD, response, NK cell expansion \\
\hline NCT03300492 & $|/| \mid$ & AML or MDS & None & $\begin{array}{l}\text { Days }+10,+15 \text { and }+20 \text { post- } \\
\text { HCT }\end{array}$ & AE, survival, response, NK cell dose \\
\hline NCT01823198 & $|/| \mid$ & High-risk AML or MDS & IL-2 & Day -8 pre-HCT & Optimal NK cell dose, survival, AE \\
\hline NCT01904136 & $|/| \mid$ & AML, MDS or CML & None & Days 7 and $28-90$ post-HCT & $\begin{array}{l}\text { MTD, AE, survival, time to engraft- } \\
\text { ment }\end{array}$ \\
\hline NCT04395092 & $\|$ & High-risk AML or MDS & None & Days $-2,+7$ and +28 post-HCT & Relapse, AE, survival \\
\hline NCT04166929 & $\|$ & AML or MDS & None & Day +7 post-HCT & Relapse \\
\hline NCT03050216 & $\|$ & R/R AML & ALT-803 & No & Response, NK cell expansion, AE \\
\hline NCT03955848 & NA & AML in remission & IL-2 & No & Survival \\
\hline \multicolumn{6}{|c|}{ Placental-derived HSPC-NK cell (CYNK-001) infusion } \\
\hline NCT04310592 & । & $\mathrm{AML}$ & None & No & MTD, AE, MRD, survival \\
\hline \multicolumn{6}{|c|}{ UCB-derived HSPC-NK cell infusion } \\
\hline NCT01619761 & I & AML, MDS, et al & None & Day-2 pre-CBT & $A E$, survival \\
\hline NCT04347616 & $|/| \mid$ & $\mathrm{R} / \mathrm{R} A M L$ & IL-2 & No & $\begin{array}{l}\text { AE, MRD, NK cell lifespan, expan- } \\
\text { sion and functional activity, } \\
\text { plasma cytokine concentration, } \\
\text { number of patients able to } \\
\text { proceed to HCT }\end{array}$ \\
\hline NCT02727803 & $\|$ & AML, MDS, et al & None & Days 30-180 post-CBT & Survival, AE \\
\hline \multicolumn{6}{|c|}{ iPSC-derived NK cell (FT516) infusion } \\
\hline NCT04023071 & 1 & R/R AML or B-cell lymphoma & $\mathrm{IL}-2$ & No & $\begin{array}{l}\text { AE, response, pharmacokinetic } \\
\text { data }\end{array}$ \\
\hline \multicolumn{6}{|c|}{ Cytokine-induced memory-like NK cell infusion } \\
\hline NCT03068819 & 1 & Relapsed AML after HCT & None & No & $A E$, response, survival \\
\hline NCT04024761 & । & $\begin{array}{l}\text { Relapsed AML, MDS or MPN after } \\
\text { HCT }\end{array}$ & IL-2 & No & $A E$, response, survival \\
\hline NCT01898793 & $|/| \mid$ & R/R AML or MDS & $\mathrm{IL}-2$ & No & MTD, response, $A E$, survival \\
\hline NCT04354025 & $\|$ & R/R AML & $\mathrm{IL}-2$ & No & $\begin{array}{l}\text { Response, number of patients } \\
\text { able to proceed to HCT, survival, } \\
\text { MRD, AE }\end{array}$ \\
\hline NCT02782546 & $\|$ & $\mathrm{R} / \mathrm{R} \mathrm{AML}$ & ALT-803 & Day +7 post-HCT & Survival, response \\
\hline \multicolumn{6}{|c|}{ CMV-induced memory-like NK cell (FATE-NK100) infusion } \\
\hline NCT03081780 & 1 & $\mathrm{R} / \mathrm{R} \mathrm{AML}$ & $\mathrm{IL}-2$ & No & $\begin{array}{l}\text { MTD, response, NK cell expansion, } \\
\text { AE, MRD, survival }\end{array}$ \\
\hline
\end{tabular}

$A E$ adverse event, $A M L$ acute myeloid leukemia, $C B T$ cord blood transplantation, $C M L$ chronic myeloid leukemia, $C M V$ cytomegalovirus, $H C T$ hematopoietic cell transplantation, HSPC hematopoietic stem and progenitor cell, IL interleukin, iPSC induced pluripotent stem cell, MDS myelodysplastic syndrome, MPN myeloproliferative neoplasm, MRD minimal residual disease, MTD maximum tolerated dose, NA not applicable, NK natural killer cell, $P B M C$ peripheral blood mononuclear cell, $R / R$ relapsed/refractory, $U C B$ umbilical cord blood

antibodies' Fc parts to increase affinity to CD16 or integrating with other therapies [127-129]. Preclinical studies investigating the efficacy of novel Fc-optimized antibodies targeting various potential antigens such as CD133, CD33, CD157 and IL-1 receptor accessory protein (IL1RAP) as well as new regimens of antibodies 
Table 2 Overview of ongoing clinical trials of antibodies for AML

\begin{tabular}{|c|c|c|c|c|c|}
\hline Antibody & Target & Regimen & Indication & Phase & Identifier \\
\hline \multicolumn{6}{|c|}{ Antibodies targeting tumor-associated antigens } \\
\hline BI 836858 & CD33 & Bl 836858 + decitabine & AML & $\|$ & NCT02632721 \\
\hline \multirow[t]{28}{*}{$\mathrm{GO}$} & CD33 & $\mathrm{GO}+\mathrm{CPX}-351$ & Relapsed AML & । & NCT03904251 \\
\hline & & $\mathrm{GO}+$ venetoclax & $\mathrm{R} / \mathrm{R} C \mathrm{CD} 33+\mathrm{AML}$ & । & NCT04070768 \\
\hline & & $\mathrm{GO}+$ pracinostat & $\mathrm{R} / \mathrm{R} C \mathrm{CD} 33+\mathrm{AML}$ & । & NCT03848754 \\
\hline & & $\mathrm{GO}+$ allo-HCT & $\begin{array}{l}\text { Average-risk CD33 + AML or MDS or } \\
\text { JMML }\end{array}$ & । & NCT01020539 \\
\hline & & $\begin{array}{l}\text { GO, midostaurin, cytarabine and dau- } \\
\text { norubicin }\end{array}$ & Newly diagnosed FLT3 mutated AML & । & NCT03900949 \\
\hline & & $\mathrm{GO}+$ talazoparib & $\mathrm{R} / \mathrm{R} C \mathrm{CD} 33+\mathrm{AML}$ & $|/| \mid$ & NCT04207190 \\
\hline & & $\begin{array}{l}\text { GO, midostaurin, cytarabine and dau- } \\
\text { norubicin }\end{array}$ & Newly diagnosed AML & $|/| \mid$ & NCT04385290 \\
\hline & & $\begin{array}{l}\text { GO, PF-04518600, venetoclax, avelumab, } \\
\text { glasdegib and azacitidine }\end{array}$ & R/R AML & $|/| \mid$ & NCT03390296 \\
\hline & & $\begin{array}{l}\text { GO, G-CSF, cladribine, cytarabine and } \\
\text { mitoxantrone }\end{array}$ & Newly diagnosed AML & $|/| \mid$ & NCT03531918 \\
\hline & & $\mathrm{GO}$ & $\mathrm{CD} 33+\mathrm{AML}$ & $\|$ & NCT03737955 \\
\hline & & $\mathrm{GO}+$ allo-HCT & Average-risk CD33 + AML or MDS & $\|$ & NCT02117297 \\
\hline & & $\mathrm{GO}+$ azacitidine & Newly diagnosed elderly AML & $\|$ & NCT00658814 \\
\hline & & $\mathrm{GO}+$ bortezomib & $\mathrm{R} / \mathrm{R} A M L$ & $\|$ & NCT04173585 \\
\hline & & $\mathrm{GO}+\mathrm{CPX}-351$ & R/R CD33 + AML or high-risk MDS & $\|$ & NCT03672539 \\
\hline & & $\mathrm{GO}+\mathrm{DLI}$ & $\mathrm{R} / \mathrm{R} \mathrm{AML}$ & $\|$ & NCT03374332 \\
\hline & & GO, mitoxantrone and etoposide & Refractory CD33 + AML & $\|$ & NCT03839446 \\
\hline & & $\begin{array}{l}\text { GO, cyclophosphamide, busulfan and } \\
\text { allo-HCT }\end{array}$ & High-risk CD33 + AML or MDS & $\|$ & NCT02221310 \\
\hline & & $\begin{array}{l}\text { GO, fludarabine, cytarabine, filgrastim- } \\
\text { sndz and idarubicin }\end{array}$ & Newly diagnosed AML or high-risk MDS & $\|$ & NCT00801489 \\
\hline & & $\begin{array}{l}\text { GO, daunorubicin, cytarabine and } \\
\text { glasdegib }\end{array}$ & Newly diagnosed AML & $\|$ & NCT04168502 \\
\hline & & GO + standard chemotherapy & Pediatric AML & $\|$ & NCT04326439 \\
\hline & & $\mathrm{GO}+$ cytarabine & Newly diagnosed AML & $\|/\| \|$ & NCT02473146 \\
\hline & & $\mathrm{GO}+$ daunorubicin + cytarabine & Elderly AML & $\|/\| \|$ & NCT02272478 \\
\hline & & $\mathrm{GO}$ & Newly diagnosed AML & III & NCT04093505 \\
\hline & & GO + standard chemotherapy & Newly diagnosed NPM1 mutated AML & III & NCT00893399 \\
\hline & & $\mathrm{GO}+$ standard chemotherapy + HCT & $\mathrm{AML}$ & III & NCT00049517 \\
\hline & & $\begin{array}{l}\text { GO, CPX-351, gilteritinib and standard } \\
\text { chemotherapy }\end{array}$ & Newly diagnosed AML & III & NCT04293562 \\
\hline & & $\begin{array}{l}\text { GO, liposomal daunorubicin, mitox- } \\
\text { antrone, fludarabine, cytarabine, } \\
\text { busulfan and cyclophosphamide }\end{array}$ & Pediatric AML & III & NCT02724163 \\
\hline & & $\mathrm{GO}$ & $\mathrm{R} / \mathrm{RCD} 33+\mathrm{AML}$ & IV & NCT03727750 \\
\hline \multirow[t]{3}{*}{ Lintuzumab Ac-225 } & CD33 & $\begin{array}{l}\text { Lintuzumab Ac-225, cladribine, cytara- } \\
\text { bine, mitoxantrone and G-CSF }\end{array}$ & $\mathrm{R} / \mathrm{R} C \mathrm{CD} 33+\mathrm{AML}$ & 1 & NCT03441048 \\
\hline & & $\begin{array}{l}\text { Lintuzumab-Ac } 225+\text { veneto- } \\
\text { clax + spironolactone }\end{array}$ & $\mathrm{R} / \mathrm{R} C \mathrm{CD} 3+\mathrm{AML}$ & $|/| \mid$ & NCT03867682 \\
\hline & & $\begin{array}{l}\text { Lintuzumab-Ac225 + venetoclax + azac- } \\
\text { itidine }\end{array}$ & $\mathrm{R} / \mathrm{R} C \mathrm{CD} 33+\mathrm{AML}$ & $|/| \mid$ & NCT03932318 \\
\hline \multirow[t]{2}{*}{ Daratumumab } & CD38 & Daratumumab & R/R AML or high-risk MDS & $\|$ & NCT03067571 \\
\hline & & Daratumumab + DLI & Relapsed AML after HCT & $|/| \mid$ & NCT03537599 \\
\hline Isatuximab & CD38 & Isatuximab + standard chemotherapy & Pediatric R/R ALL or AML & $\|$ & NCT03860844 \\
\hline \multirow[t]{3}{*}{ Magrolimab } & CD47 & Magrolimab + atezolizumab & R/R AML & । & NCT03922477 \\
\hline & & Magrolimab + azacitidine & AML or MDS & । & NCT03248479 \\
\hline & & Magrolimab + azacitidine + venetoclax & AML & $|/ /|$ & NCT04435691 \\
\hline
\end{tabular}


Table 2 (continued)

\begin{tabular}{|c|c|c|c|c|c|}
\hline Antibody & Target & Regimen & Indication & Phase & Identifier \\
\hline \multirow[t]{4}{*}{ Cusatuzumab } & \multirow[t]{4}{*}{ CD70 } & $\begin{array}{l}\text { Cusatuzumab, azacitidine and veneto- } \\
\text { clax }\end{array}$ & AML & । & NCT04150887 \\
\hline & & Cusatuzumab + azacitidine & Newly diagnosed AML or high-risk MDS & । & NCT04241549 \\
\hline & & Cusatuzumab + azacitidine & Newly diagnosed AML or high-risk MDS & $|/| \mid$ & NCT03030612 \\
\hline & & Cusatuzumab + azacitidine & Newly diagnosed AML & $\|$ & NCT04023526 \\
\hline SEA-CD70 & CD70 & SEA-CD70 & AML or MDS & । & NCT04227847 \\
\hline \multirow[t]{2}{*}{ IMGN632 } & \multirow[t]{2}{*}{ CD123 } & IMGN632 & $\begin{array}{l}\text { R/R CD123 + AML or other hematologic } \\
\text { malignancies }\end{array}$ & $|/| \mid$ & NCT03386513 \\
\hline & & IMGN632, venetoclax and azacitidine & $\mathrm{CD} 123+\mathrm{AML}$ & $|/| \mid$ & NCT04086264 \\
\hline ASP1235 & FLT3 & ASP1235 & AML & 1 & NCT02864290 \\
\hline FLYSYN & FLT3 & FLYSYN & AML & $|/| \mid$ & NCT02789254 \\
\hline \multirow[t]{3}{*}{ Atezolizumab } & \multirow[t]{3}{*}{ PD-L1 } & Atezolizumab + magrolimab & $\mathrm{R} / \mathrm{R} \mathrm{AML}$ & 1 & NCT03922477 \\
\hline & & Atezolizumab + gilteritinib & R/R FLT3 mutated AML & $1 / 1 \mid$ & NCT03730012 \\
\hline & & Atezolizumab + guadecitabine & R/R AML, CML or MDS & $|/| \mid$ & NCT02935361 \\
\hline Avelumab & PD-L1 & $\begin{array}{l}\text { Avelumab, GO, PF-04518600, venetoclax, } \\
\text { glasdegib and azacitidine }\end{array}$ & R/R AML & $|/| \mid$ & NCT03390296 \\
\hline Durvalumab & PD-L1 & Durvalumab + azacitidine & Newly diagnosed MDS or elderly AML & $\|$ & NCT02775903 \\
\hline \multicolumn{6}{|c|}{ Antibodies targeting NK cell inhibitory receptors } \\
\hline \multirow[t]{10}{*}{ Pembrolizumab } & \multirow[t]{10}{*}{ PD-1 } & Pembrolizumab & Relapsed AML or MDS after HCT & I & $\begin{array}{l}\text { NCT03286114 } \\
\text { NCT02981914 }\end{array}$ \\
\hline & & Pembrolizumab + decitabine & AML or MDS & । & NCT03969446 \\
\hline & & Pembrolizumab + AMG 330 & R/R AML & । & NCT04478695 \\
\hline & & Pembrolizumab & Non-favorable risk AML & $\|$ & NCT02771197 \\
\hline & & Pembrolizumab & Elderly AML in remission & $\|$ & NCT02708641 \\
\hline & & Pembrolizumab + cytarabine & $\mathrm{R} / \mathrm{R} A M L$ & $\|$ & NCT02768792 \\
\hline & & Pembrolizumab + azacitidine & NPM1 mutated AML & $\|$ & NCT03769532 \\
\hline & & Pembrolizumab + azacitidine & $\begin{array}{l}\text { R/R AML or newly diagnosed elderly } \\
\text { AML }\end{array}$ & $\|$ & NCT02845297 \\
\hline & & $\begin{array}{l}\text { Pembrolizumab, azacitidine and vene- } \\
\text { toclax }\end{array}$ & Elderly newly diagnosed AML & $\|$ & NCT04284787 \\
\hline & & $\begin{array}{l}\text { Pembrolizumab, cytarabine, idarubicin, } \\
\text { daunorubicin and HCT }\end{array}$ & Newly diagnosed AML & $\|$ & NCT04214249 \\
\hline \multirow[t]{10}{*}{ Nivolumab } & \multirow[t]{10}{*}{ PD-1 } & Nivolumab & High-risk AML or MDS after HCT & । & NCT04361058 \\
\hline & & Nivolumab & Relapsed AML after HCT & । & NCT01822509 \\
\hline & & Nivolumab + ipilimumab & AML or MDS & । & NCT02846376 \\
\hline & & Nivolumab + ipilimumab & High-risk R/R AML or MDS & । & NCT03600155 \\
\hline & & $\begin{array}{l}\text { Nivolumab, CDX-1401, poly ICLC and } \\
\text { decitabine }\end{array}$ & AML or MDS & । & NCT03358719 \\
\hline & & Nivolumab + azacytidine & Pediatric R/R AML & $|/| \mid$ & NCT03825367 \\
\hline & & Nivolumab & AML in remission at high-risk for relapse & $\|$ & NCT02532231 \\
\hline & & Nivolumab & AML in remission & $\|$ & NCT02275533 \\
\hline & & Nivolumab, azacitidine and ipilimumab & AML & $\|$ & NCT02397720 \\
\hline & & $\begin{array}{l}\text { Nivolumab, azacitidine, midostaurin, } \\
\text { decitabine and cytarabine }\end{array}$ & $\begin{array}{l}\text { Elderly newly diagnosed AML or high- } \\
\text { risk MDS }\end{array}$ & $\|/\| \|$ & NCT03092674 \\
\hline Tislelizumab & PD-1 & $\begin{array}{l}\text { Tislelizumab, DNA hypomethylating } \\
\text { agent and chemotherapy }\end{array}$ & AML & $\|$ & NCT04541277 \\
\hline Spartalizumab & PD-1 & Spartalizumab, MBG453 and decitabine & AML or high-risk MDS & । & NCT03066648 \\
\hline \multirow[t]{5}{*}{ Ipilimumab } & \multirow[t]{5}{*}{ CTLA-4 } & Ipilimumab & Relapsed AML after HCT & । & NCT01822509 \\
\hline & & Ipilimumab + nivolumab & High-risk R/R AML or MDS & I & NCT03600155 \\
\hline & & Ipilimumab + nivolumab & AML or MDS & । & NCT02846376 \\
\hline & & Ipilimumab + decitabine & R/R AML or MDS & । & NCT02890329 \\
\hline & & Ipilimumab + DLI & Relapsed AML, MDS or MPN after HCT & । & NCT03912064 \\
\hline
\end{tabular}


Table 2 (continued)

\begin{tabular}{|c|c|c|c|c|c|}
\hline Antibody & Target & Regimen & Indication & Phase & Identifier \\
\hline & & Ipilimumab, nivolumab and azacitidine & $\mathrm{AML}$ & $\|$ & NCT02397720 \\
\hline \multirow[t]{3}{*}{ MBG453 } & $\mathrm{TIM}-3$ & MBG453, HDM201 and venetoclax & AML or high-risk MDS & I & NCT03940352 \\
\hline & & MBG453, spartalizumab and decitabine & AML or high-risk MDS & 1 & NCT03066648 \\
\hline & & MBG453, azacitidine and venetoclax & Newly diagnosed AML & $\|$ & NCT04150029 \\
\hline \multicolumn{6}{|l|}{ BiKE or TriKE } \\
\hline GTB-3550 & CD16/IL-15/CD33 & GTB-3550 & $\mathrm{CD} 33+\mathrm{R} / \mathrm{R}$ AML or high-risk MDS & $|/| \mid$ & NCT03214666 \\
\hline
\end{tabular}

combined with NK cell transfer exhibited promising results and these strategies can be valuable to be conducted in future clinical trials [130-136]. Antibody-drug conjugates (ADCs) and antibody-radio conjugates are promising strategies to enhance the antibody potency as well, and they yield superior clinical impacts on AML patients [137-141]. Gemtuzumab ozogamicin (GO), the combination of anti-CD33 antibody with anti-neoplastic agent calicheamicin, is currently the only ADC approved by the Food and Drug Administration (FDA) for the treatment of newly diagnosed and R/R CD33+AML [142-144]. Latest preclinical findings of more novel ADCs targeting CD33, CD37, FLT3, C-type lectin-like molecule 1 (CLL-1; also known as C-type lectin domain family 12, member A, CLEC12A) and leukocyte immunoglobulin-like receptor subfamily B4 (LILRB4) highlight their clinical potential for the treatment of AML [145-151].

In addition, ligands of NK cell inhibitory or activating receptors on AML cells can also be the targets of antibodies. It was reported that NK-resistant feature of mixed lineage leukemia (MLL)-rearranged leukemia could be overcome by anti-CD19 antibody and antiCD33 antibody-induced ADCC, and the effects could be further amplified with pan-MHC-I antibodies, suggesting the utilization of a triple immunotherapy approach, including KIR-mismatched NK cell transfer, antibodies against tumor-associated antigens and inhibitory KIR blockade, for the treatment of MLL-rearranged leukemia [152]. The expression level of inhibitory immune checkpoint molecule PD-L1 on AML blasts is an important negative prognostic factor [153]. Hypomethylating agents, while enhancing anti-tumor immune response, can concurrently dampen immune response by upregulating PD-1 and PD-L1 expression, providing the rationale of combination therapies of PD-L1 inhibitors and hypomethylating agents $[154,155]$. Other antibodies targeting TNF family members on AML cells, such as glucocorticoid-induced TNFR-related protein ligand (GITRL) and receptor activator for NF- $\mathrm{kB}$ ligand (RANKL), were manifested against primary AML cells in preclinical studies through the prevention of inhibitory signals into NK cells as well as the induction of ADCC [156-158]. Despite the inevitable reduction in activating signals upon antibodies binding to ligands of activating receptors, NKG2D-Fc and NKp80-Fc fusion proteins were shown to be able to compensate for it by inducing ADCC to potentiate NK cell killing of AML cells [159, 160].

\section{Antibodies targeting NK cell inhibitory receptors}

Inhibitory receptors in NK cells serve as the sources of cancer immune escape, making them ideal targets for immunotherapy (Fig. 2d). Over the past decades, the number of inhibitory receptors identified in NK cells has been increasing. Apart from MHC-I-specific inhibitory receptors KIRs, LIRs and CD94/NKG2A, other immune checkpoints on NK cells have been shown to cause dysfunction such as programmed cell death-1 (PD-1), cytotoxic $\mathrm{T}$ lymphocyte-associated antigen-4 (CTLA-4), T-cell immunoglobulin domain and mucin domain-3 (TIM-3), T-cell immunoglobulin and immunoreceptor tyrosine-based inhibitory motif domain (TIGIT), siglec-7/9 and CD200R [161].

Just as the benefit of KIR-ligand mismatch between donors and recipients in improving the outcome of HCT, pharmacologic KIR blockade by anti-KIR antibodies can prevent the KIR-HLA-C interaction and augment NK cell function as well. IPH2101 and IPH2102 (lirilumab) are antibodies targeting KIR2D and both were reported to be safe in the treatment of elderly patients with AML in first CR, though the leukemia-free survival with lirilumab did not compare favorably to placebo in a phase II study [162-164]. The combination of lirilumab with azacitidine also did not display significant improvement in $\mathrm{R} / \mathrm{R} A M L$ in terms of response rate (overall response 
rate, ORR 14\%) or survival (median OS 4.2 months), and the relevant clinical trial (NCT02399917) was terminated early due to unsatisfactory results [165]. LIR-1 or NKG2A blockade resulted in increased NK cell cytotoxicity against AML, suggesting that the cocktail consisting of anti-KIR, anti-LIR-1 and anti-NKG2A antibodies may be a necessary option for better efficacy $[166,167]$. Anti-PD-1 antibody (nivolumab and pembrolizumab) and anti-CTLA4 antibody (ipilimumab) are FDA-approved immune checkpoint inhibitors mainly for the treatment of various solid tumors, while their applications in the field of AML are still at the exploratory stage. Nivolumab in combination with idarubicin and cytarabine produced an encouraging response rate (ORR 80\%) and OS (median OS 18.5 months) in patients with newly diagnosed AML [168]. The combination therapy of nivolumab and azacitidine was feasible in patients with $\mathrm{R} / \mathrm{R} \mathrm{AML}$, and the addition of ipilimumab further upregulated the clinical efficacy (ORR $33 \%$ vs $44 \%$; median OS 6.4 vs 10.5 months) [169, 170]. And nivolumab maintenance was safe and feasible in high-risk AML patients in CR (1-year CR duration 71\%; 1-year OS 86\%) [171]. The outcomes of pembrolizumab administered in combined with decitabine or following high-dose cytarabine in $R / R$ AML (ORR 10\% and 46\%; median OS 7 and 8.9 months, respectively) suggested that immune checkpoint inhibitors after intensive cytotoxic chemotherapy may be a better option [172, 173]. A phase I/Ib study demonstrated the safety and efficacy of ipilimumab monotherapy in AML patients with post-HCT relapse (ORR 32\%; 1-year OS 49\%) [174]. As for anti-TIM-3 antibody MBG453, the combination therapy with decitabine was safe and well-tolerated and exhibited encouraging preliminary response rates for AML in a phase Ib study (ORR 29\% for both newly diagnosed and R/R AML) [175]. However, caution should be paid to checkpoint inhibitors, since exposure can lead to a significantly increased risk of GvHD [168, 174, 176, 177]. Furthermore, the prognostic effect of TIGIT in the bone marrow post-HCT as well as the involvement of CD137-CD137L and CD200-CD200R interactions in immune evasion raise the possibility of attacking other inhibitory receptors with antibodies as potent immunotherapeutic strategies in the near future [53, 178-180].

\section{BiKE and TriKE}

Bi-specific killer cell engager (BiKE) and tri-specific killer cell engager (TriKE) are the recombinant agents of bivalent and trivalent single-chain variable fragments $(\mathrm{scFv})$, serving as immunologic synapses between NK cells and tumor cells. They retain the specificity of original antibodies and, at the same time, minimize the size of antibodies to increase distribution. CD16-directed BiKE and
TriKE trigger NK cell activation through CD16 signaling and against tumor cells with target antigens in a highly efficient manner (Fig. 2c) [181].

Wiernik et al. designed a novel full humanized BiKE that specifically binds to both CD16 and CD33 $(\mathrm{CD} 16 \times 33 \mathrm{BiKE})$. NK cell cytotoxicity and cytokine release were specifically triggered by $\mathrm{CD} 16 \times 33 \mathrm{BiKE}$ when cultured with CD33+AML cell lines and primary AML cells, and the effector functions of NK cells were further enhanced when combined with adisintegrin and metalloprotease-17 (ADAM17) inhibitor which prevents CD16 shedding [182]. Lately, the same research group designed a TriKE by incorporating a novel modified human IL-15 crosslinker into CD16 $\times 33$ BiKE, which provided a signal for NK cell self-sustaining proliferation and activation [183]. A phase I/II clinical trial of CD16 $\times 33 \times$ IL-15 TriKE (GTB-3550) for the treatment of CD33+R/R AML is underway (NCT03214666). TriKEs of linking anti-CD16 scFv to either two scFv against the same antigen (such as CD16 $\times 33 \times 33$ TriKE) or two scFv against two different antigens (such as CD16 $\times 33 \times 123$ TriKE) displayed greater binding affinity and superior NK cell cytotoxic potency toward AML cells compared to BiKE $[184,185]$. Since CD33 is abundantly expressed on healthy myeloid cells as well, NKG2DLs, which are leukemia cell-restricted expressed, become promising targets. CD16 $\times$ NKG2D BiKE displayed increased affinity to CD16 and induced superior leukemia cell killing compared to the engineered NKG2D-Fc fusion protein [186]. Besides, CD16 $\times$ CLL- $1 \times$ IL-15 TriKE displayed robust NK cell activity against AML in vitro and in vivo [187]. These molecules constitute attractive candidates for personalized immunotherapy for AML based on preclinical findings.

\section{Cytokines}

Cytokines, including IL-2, IL-12, IL-15, IL-18 and IL-21, play an important role in NK cell proliferation, activation and effector function (Fig. 2e). Ex vivo stimulation with $10 \mathrm{ng} / \mathrm{mL}$ IL-2 or $50 \mathrm{ng} / \mathrm{mL}$ IL-15 was reported to be optimal for NK cell expansion and enable NK cells of AML patients with recovered function through upregulating activating receptors such as NKp30, NKp46, NKG2C and NKG2D [188-190]. IL-2 monotherapy may not be clinically efficacious in AML patients [191-194]. But, IL-2 in conjunction with histamine dihydrochloride has been proposed as a maintenance therapy in AML, resulting in improved leukemia-free survival [195, 196]. The mechanism of this therapy may partially be the induction of a striking expansion of immunocompetent CD56 ${ }^{\text {bright }}$ NK cell subpopulations [197]. A phase I study identified IL-15 superagonist complex ALT-803 as a safe agent in the treatment of elderly AML patients who 
relapsed after HCT and the potential efficacy is expected to be reported (NCT01885897) [198]. And the feasibility of using ALT-803 as an relapse prophylaxis for AML patients after HCT is under assessment (NCT02989844). Furthermore, genetically engineered AML cells with DNA encoding IL-12 or IL-15 have been constructed to reduce toxicities associated with systemic administration of cytokines [199, 200]. A clinical trial (NCT02483312) is ongoing to test engineered AML cells expressing IL-12 in AML patients that cannot have HCT.

Cytokines have also been widely incorporated in the NK cell transfer as a process of 'priming or arming' in order to increase NK cell proliferation and expansion. However, the effect is short-lasting and the short-term NK cell persistence within patients might limit their clinical use. Remarkably, NK cells preactivated with a cocktail of cytokines (IL-12, IL-15 and IL-18) exhibited augmented anti-leukemia responses to restimulation for weeks to months regardless of inhibitory KIR-KIR ligand interactions [201-203]. Those cytokine-induced memory-like (CIML) NK cells with adaptive immune properties represent a promising approach to enhancing adoptive NK cell transfer. The first-in-human trial of adoptive transfer of CIML NK cells in elderly patients with R/R AML showed successful induction of remission (ORR 67\%) without the cause of CRS, GvHD or neurotoxicity [204, 205]. Patient outcomes were negatively associated with the frequency of $C D 8 \alpha+$ donor NK cells and the expression of NKG2A on CIML NK cells within patients [205]. Encouraging preliminary data give us confidence on more ongoing early phase clinical trials of CIML NK cells for R/R AML (NCT04354025, NCT02782546, NCT01898793, NCT03068819) [206, 207].

\section{Drugs with immunomodulatory function}

Many anti-tumor drugs have been illustrated with immunomodulatory properties to enhance endogenous NK cell function against AML in recent years (Fig. 2f). Since AML cells resist to NK cell-mediated killing by changing the expression of their surface ligands for various NK cell receptors and these phenotypic defects correlate with clinical outcomes, drugs that are capable of restoring ligand expressions on AML cells can render them more susceptible to NK cell killing [64].

Firstly, hypomethylating agents azacitidine and decitabine can upregulate the expression of NKG2DL on AML cells by reversing epigenetically silenced genes, resulting in enhanced NK cell-mediated immunity through the immune recognition mediated by NKG2DNKG2DL engagement [208]. They concurrently increase the expression of tissue inhibitor of metalloproteinases-3 (TIMP3), an ADAM17 inhibitor, thus reducing the shedding of soluble NKG2DLs from AML cells [209]. Histone deacetylase inhibitors (trichostatin A and valproic acid), differentiation-promoting drugs (vitamin D3, bryostatin 1 and all-trans-retinoic acid) and hydroxyurea all somehow show the potential of upregulating the expression of NKG2DLs on AML cells, while dinaciclibtreated AML is associated with the downregulation of inhibitory NK ligand HLA-E on AML cells, consequently inducing potent NK cell anti-tumor immunity [208, 210-213]. Then, immunomodulatory drugs lenalidomide and pomalidomide exert anti-leukemia effects both directly and via NK cell-mediated immunostimulatory activities along with downregulation of HLA-class I on AML blasts [214]. The combination therapies containing the aforementioned drugs for AML are widely used in clinical practice and also in clinical trials. Besides, natural compounds or their derivatives such as safrole, $\alpha$-phellandrene, casticin and ouabain can also promote NK cell activity against AML cells [215-218]. In addition, novel agents with immunomodulatory function were proposed in fundamental researches, providing therapeutic implications in AML. For instance, vascular endothelial growth factor receptor (VEGFR)-3 antagonist restored NK cell cytotoxicity with an increased IFN- $\gamma$ level $[219,220]$, and the therapeutic efficacy of adoptive NK cell transfer could be enhanced by a TGF- $\beta$ receptor kinase inhibitor galunisertib [221]. With the clarification of mechanisms of anti-tumor drugs, combining pharmacological approaches with other NK cell-based immunotherapies may strengthen the efficacy and provide a clinical benefit for AML patients.

\section{Conclusions and perspectives}

Results from current preclinical studies and clinical trials highlight the significant contribution of numerous NK cell-based immunotherapies in activating the reconstitution of NK cells against AML. Adoptive NK cell transfer has expanded the option of cellular immunotherapy as a feasible strategy to induce and maintain remission. Strategies of manipulating adoptively transferred NK cells, such as CAR modification and cytokine induction, may further enhance the therapeutic efficacy. Other strategies, such as immune checkpoint inhibitors, BiKE/TriKE and immunomodulatory drugs, can reverse endogenous NK cell anergy, contributing to an increasing dimensions of utilizing NK cells to fight AML.

There are several advantages in NK cell-based immunotherapy. Firstly, NK cells detect tumor cells through native receptors in a non-MHC-restricted manner and also mediate ADCC, expanding their clinical applications. Secondly, as compared with T-cell therapy, NKcell therapy has better safety profiles with rare instances of GvHD and CRS due to limited lifespan and distinct 
cytokines produced [71]. Thirdly, NK cells have the advantage of "off-the-shelf" manufacturing, making it easy to be prepared under good manufacturing practice standards and convenient to universally treat patients with increased speed of administration [222-225]. However, the field of NK cell-based immunotherapy still faces several challenges. In fact, short lifespan of NK cells narrows the therapeutic window, leading to a relatively short duration of response in most patients [88, 90, 95, 226]. Besides, tumors can escape from NK cell cytotoxicity via immunosuppressive tumor microenvironment or by shedding soluble ligands that activate NK receptors [54, 60]. Finally, transduction efficiency of CAR-NK cells is another aspect needed to be improved [227].

In the future, the efficacy of NK cell-based immunotherapy is waiting to be confirmed in large sample sizes and in great detail. The optimal dosage and schedule of adoptive NK cell transfer as well as the feasible sources and manipulation methods for NK cells have yet to be evaluated [228]. It seems logical to combine various NK cell-based immunotherapies to utilize the full potential of NK cells, such as stimulating both target-specific lysis and ADCC effects as well as simultaneously boosting endogenous $\mathrm{NK}$ cells and receiving exogenous NK cells $[131,135,136,229,230]$. Also, it is reasonable to integrate them with well-established AML treatments or novel agents which may provide synergistic effects and improve clinical response [94]. As for preclinical researches, a better knowledge of the mechanisms of NK cell dysfunction and NK cell-based immunotherapy in AML could broaden the application of NK cells and help the discovery of additional new therapeutic opportunities, including new targets and potential combination therapies. Strategies of wisely using cytokines, such as CMIL NK cells and the transduction of genes encoding cytokines into NK cells, seem to prolong the duration of NK cell persistence in some degree, but more efforts are warranted to figure out approaches to enhance tumorimmune surveillance long term [17, 183, 206, 231]. Taking advantage of multi-omics and information technology, investigation of both donor NK cell-intrinsic and host factors which may contribute to treatment response or resistance can provide an array of biomarkers in donor and patient selection. Overall, there is a bright future in NK cell-based immunotherapy for AML.

\footnotetext{
Abbreviations

ADAM17: A disintegrin and metalloprotease-17; ADC: Antibody-drug conjugate; ADCC: Antibody-dependent cell-mediated cytotoxicity; AE: Adverse event; ALL: Acute lymphoblastic leukemia; allo-HCT: Allogeneic hematopoietic cell transplantation; AML: Acute myeloid leukemia; BiKE: Bi-specific killer cell engager; CAR: Chimeric antigen receptor; CBT: Cord blood transplantation; CD: Cluster of differentiation; clgTCR: Immunoglobulin-based chimeric T cell receptor; CIML: Cytokine-induced memory-like; CML: Chronic myeloid
}

leukemia; CMV: Cytomegalovirus; CR: Complete remission; CRS: Cytokine release syndrome; CTLA-4: Cytotoxic T lymphocyte-associated antigen-4; CLEC12A: C-type lectin domain family 12, member A; DC: Dendritic cell; DLI: Donor lymphocyte infusion; CLL-1: C-type lectin-like molecule 1; DNAM-1: DNAX accessory molecule-1; FDA: Food and Drug Administration; FLT3: FMS-like tyrosine kinase 3; G-CSF: Granulocyte colony-stimulating factor; GITR: Glucocorticoid-induced TNFR-related protein; GO: Gemtuzumab ozogamicin; GvHD: Graft-versus-host disease; GvL: Graft-versus-leukemia; HCT: Hematopoietic cell transplantation; HLA: Human leukocyte antigen; HSC: Hematopoietic stem cell; HSPC: Hematopoietic stem and progenitor cell; IDO: Indoleamine 2,3 dioxygenase; IFN: Interferon; IL: Interleukin; IL1RAP: IL-1 receptor accessory protein; IL2DT: IL-2 diphtheria toxin; iPSC: Induced pluripotent stem cell; JMML: Juvenile myelomonocytic leukemia; KIR: Killer immunoglobulin-like receptor; LILRB4: Leukocyte immunoglobulin-like receptor subfamily B4; LIR: Leukocyte immunoglobulin-like receptor; LSC: Leukemia stem cell; MACS: Magnetic cell sorting; MDS: Myelodysplastic syndrome; MDSC: Myeloid-derived suppressor cell; MHC: Major histocompatibility complex; MIC: MHC class I chain-related protein; MLL: Mixed lineage leukemia; MPN: Myeloproliferative neoplasm; MRD: Minimal residual disease; MTD: Maximum tolerated dose; NA: Not applicable; NCR: Natural cytotoxicity receptor; NK: Natural killer cell; NKG2A: Natural killer group 2A; NKG2C: Natural killer group 2C; NKG2D: Natural killer group 2D; NKG2DL: NKG2D ligand; NPM1: Nucleophosmin 1; ORR: Overall response rate; PBMC: Peripheral blood mononuclear cell; PD-1: Programmed cell death1; PD-L1: Programmed cell death ligand-1; PD-L2: Programmed cell death ligand-2; RANKL: Receptor activator for NF-KB ligand; R/R: Relapsed/refractory; scFv: Single chain variable fragment; Siglec: Sialic acid-binding immunoglobulin-like lectin; TAM: Tumor-associated macrophage; TGF: Transforming growth factor; TIGIT:T-cell immunoglobulin and immunoreceptor tyrosine-based inhibitory motif domain; TIM-3: T-cell immunoglobulin domain and mucin domain-3; TIMP3: Tissue inhibitor of metalloproteinases-3; TNF: Tumor necrosis factor; TNFR: Tumor necrosis factor receptor; Treg: Regulatory T cell; TriKE: Tri-specific killer cell engager; UCB: Umbilical cord blood; ULBP: UL16-binding protein; VEGFR: Vascular endothelial growth factor receptor.

\section{Acknowledgements \\ Not applicable.}

\section{Authors' contributions}

JX wrote the manuscript and prepared the tables and figures. TN critically reviewed and edited the manuscript. Both authors read and approved the final manuscript.

Funding

No funding was provided for this review.

Availability of data and materials

The material supporting the information of this review has been included within the article.

Ethics approval and consent to participate

This is not applicable for this review.

Consent for publication

This is not applicable for this review.

\section{Competing interests}

The authors declare that they have no competing interests.

Received: 21 September 2020 Accepted: 11 November 2020

Published online: 07 December 2020

\section{References}

1. Lai C, Doucette K, Norsworthy K. Recent drug approvals for acute myeloid leukemia. J Hematol Oncol. 2019;12(1):100.

2. Blum WG, Mims AS. Treating acute myeloid leukemia in the modern era: a primer. Cancer. 2020;126:4668-77. 
3. Ball B, Stein EM. Which are the most promising targets for minimal residual disease-directed therapy in acute myeloid leukemia prior to allogeneic stem cell transplant? Haematologica. 2019;104(8):1521-31.

4. Lichtenegger FS, Krupka C, Haubner S, Köhnke T, Subklewe M. Recent developments in immunotherapy of acute myeloid leukemia. J Hematol Oncol. 2017;10(1):142.

5. Farkona S, Diamandis EP, Blasutig IM. Cancer immunotherapy: the beginning of the end of cancer? BMC Med. 2016;14(1):1-18.

6. Beatty GL, Gladney WL. Immune escape mechanisms as a guide for cancer immunotherapy. Clin Cancer Res. 2015;21(4):687-92.

7. Sathyanarayanan V, Neelapu SS. Cancer immunotherapy: strategies for personalization and combinatorial approaches. Mol Oncol. 2015;9(10):2043-53.

8. Vasekar M, Rizvi S, Liu X, Vrana KE, Zheng H. Novel immunotherapies for hematological malignancies. Curr Mol Pharmacol. 2016;9(3):264-71.

9. Im A, Pavletic SZ. Immunotherapy in hematologic malignancies: past, present, and future. J Hematol Oncol. 2017;10(1):94.

10. Fang F, Xiao W, Tian Z. NK cell-based immunotherapy for cancer. Semin Immunol. 2017;31:37-54.

11. Cheng M, Chen Y, Xiao W, Sun R, Tian Z. NK cell-based immunotherapy for malignant diseases. Cell Mol Immunol. 2013;10(3):230-52.

12. Hu W, Wang G, Huang D, Sui M, Xu Y. Cancer immunotherapy based on natural killer cells: current progress and new opportunities. Front Immunol. 2019:10:1205.

13. Valipour B, Abedelahi A, Naderali E, Velaei K, Movassaghpour A, Talebi M, Montazersaheb S, Karimipour M, Darabi M, Chavoshi H. Cord blood stem cell derived CD16+ NK cells eradicated acute lymphoblastic leukemia cells using with anti-CD47 antibody. Life Sci. 2020;242:1 17223.

14. Tanaka J, Tanaka N, Wang Y-H, Mitsuhashi K, Ryuzaki M, lizuka Y, Watanabe A, Ishiyama M, Shinohara A, Kazama H. Phase I study of cellular therapy using ex vivo expanded natural killer cells from autologous peripheral blood mononuclear cells combined with rituximab-containing chemotherapy for relapsed CD20-positive malignant lymphoma patients. Haematologica. 2020;105(4):e190.

15. Bachanova V, Sarhan D, DeFor TE, Cooley S, Panoskaltsis-Mortari A, Blazar BR, Curtsinger JM, Burns L, Weisdorf DJ, Miller JS. Haploidentical natural killer cells induce remissions in non-Hodgkin lymphoma patients with low levels of immune-suppressor cells. Cancer Immunol Immunother. 2018;67(3):483-94.

16. Zhu H, Blum RH, Bjordahl R, Gaidarova S, Rogers P, Lee TT, Abujarour R, Bonello GB, Wu J, Tsai P-F. Pluripotent stem cell-derived NK cells with high-affinity noncleavable CD16a mediate improved antitumor activity. Blood. 2020;135(6):399-410.

17. Liu E, Marin D, Banerjee P, Macapinlac HA, Thompson P, Basar R, Nassif Kerbauy L, Overman B, Thall P, Kaplan M. Use of CAR-transduced natural killer cells in CD19-positive lymphoid tumors. N Engl J Med. 2020;382(6):545-53.

18. Oelsner S, Waldmann A, Billmeier A, Röder J, Lindner A, Ullrich E, Marschalek R, Dotti G, Jung G, Große-Hovest L. Genetically engineered CAR NK cells display selective cytotoxicity against FLT3-positive B-ALL and inhibit in vivo leukemia growth. Int J Cancer. 2019;145(7):1935-45.

19. Xu Y, Liu Q, Zhong M, Wang Z, Chen Z, Zhang Y, Xing H, Tian Z, Tang K, Liao X. 2B4 costimulatory domain enhancing cytotoxic ability of antiCD5 chimeric antigen receptor engineered natural killer cells against T cell malignancies. J Hematol Oncol. 2019;12(1):49.

20. You F, Wang Y, Jiang L, Zhu X, Chen D, Yuan L, An G, Meng H, Yang L. A novel CD7 chimeric antigen receptor-modified NK-92Ml cell line targeting T-cell acute lymphoblastic leukemia. Am J Cancer Res. 2019;9(1):64-78.

21. Daher M, Basar R, Gokdemir E, Baran N, Uprety N, Nunez Cortes AK, Mendt M, Kerbauy LN, Banerjee PP, Hernandez Sanabria M. Targeting a cytokine checkpoint enhances the fitness of armored cord blood CARNK cells. Blood. 2020. https://doi.org/10.1182/blood.2020007748.

22. Gang M, Marin ND, Wong P, Neal CC, Marsala L, Foster M, Schappe T, Meng W, Tran J, Schaettler M. CAR-modified memory-like NK cells exhibit potent responses to NK-resistant lymphomas. Blood. 2020;136:2308-18.

23. Schmied BJ, Lutz MS, Riegg F, Zekri L, Heitmann JS, Bühring H-J, Jung G, Salih HR. Induction of NK cell reactivity against B-cell acute lymphoblastic leukemia by an Fc-optimized FLT3 antibody. Cancers. 2019;11(12):1966.
24. Vyas M, Schneider A-C, Shatnyeva O, Reiners KS, Tawadros S, Kloess S, Köhl U, Hallek M, Hansen HP, Pogge Von trandmann E. Mono-and dualtargeting triplebodies activate natural killer cells and have anti-tumor activity in vitro and in vivo against chronic lymphocytic leukemia. Oncoimmunology. 2016;5(9):e1211220.

25. Ernst D, Williams BA, Wang X-H, Yoon N, Kim K-P, Chiu J, Luo ZJ, Hermans KG, Krueger J, Keating A. Humanized anti-CD123 antibody facilitates NK cell antibody-dependent cell-mediated cytotoxicity (ADCC) of Hodgkin lymphoma targets via ARF6/PLD-1. Blood Cancer J. 2019;9(2):1-11.

26. Gupta U, Hira SK, Singh R, Paladhi A, Srivastava P, Manna PP. Essential role of TNF-a in gamma c cytokine aided crosstalk between dendritic cells and natural killer cells in experimental murine lymphoma. Int Immunopharmacol. 2020;78:106031.

27. Hemati M, Nejad ZR, Shokri M-R, Ghahremanfard F, Mohammadkhani MM, Kokhaei P. IL-27 impact on NK cells activity: implication for a robust anti-tumor response in chronic lymphocytic leukemia. Int Immunopharmacol. 2020;82:106350.

28. Villa-Álvarez M, Sordo-Bahamonde C, Lorenzo-Herrero S, Gonzalez-Rodriguez AP, Payer AR, Gonzalez-Garcia E, Villa-Álvarez MC, López-Soto A, Gonzalez S. Ig-like transcript 2 (ILT2) blockade and lenalidomide restore NK cell function in chronic lymphocytic leukemia. Front Immunol. 2018;9:2917.

29. Chang M-C, Cheng H-I, Hsu K, Hsu Y-N, Kao C-W, Chang Y-F, Lim K-H, Chen CG. NKG2A down-regulation by dasatinib enhances natural killer cytotoxicity and accelerates effective treatment responses in patients with chronic myeloid leukemia. Front Immunol. 2019;9:3152.

30. Mizoguchi I, Yoshimoto T, Katagiri S, Mizuguchi J, Tauchi T, Kimura Y, Inokuchi K, Ohyashiki JH, Ohyashiki K. Sustained upregulation of effector natural killer cells in chronic myeloid leukemia after discontinuation of imatinib. Cancer Sci. 2013;104(9):1146-53.

31. Cucè M, Cantafio MEG, Siciliano MA, Riillo $C$, Caracciolo $D$, Scionti F, Staropoli N, Zuccalà V, Maltese L, Di Vito A. Trabectedin triggers direct and NK-mediated cytotoxicity in multiple myeloma. J Hematol Oncol. 2019;12(1):32.

32. Sinha C, Cunningham LC. An overview of the potential strategies for NK cell-based immunotherapy for acute myeloid leukemia. Pediatr Blood Cancer. 2016;63(12):2078-85.

33. Baragano Raneros A, López-Larrea C, Suárez-Álvarez B. Acute myeloid leukemia and NK cells: two warriors confront each other. Oncoimmunology. 2019;8(2):e1539617.

34. Spits H, Artis D, Colonna M, Diefenbach A, Di Santo JP, Eberl G, Koyasu S, Locksley RM, McKenzie AN, Mebius RE. Innate lymphoid cells_-a proposal for uniform nomenclature. Nat Rev Immunol. 2013;13(2):145-9.

35. Cooper MA, Fehniger TA, Caligiuri MA. The biology of human natural killer-cell subsets. Trends Immunol. 2001;22(11):633-40.

36. Waldhauer I, Steinle A. NK cells and cancer immunosurveillance. Oncogene. 2008;27(45):5932-43.

37. Campbell KS, Hasegawa J. Natural killer cell biology: an update and future directions. J Allergy Clin Immunol. 2013;132(3):536-44.

38. Handgretinger R, Lang P, André MC. Exploitation of natural killer cells for the treatment of acute leukemia. Blood. 2016;127(26):3341-9.

39. Pende D, Falco M, Vitale M, Cantoni C, Vitale C, Munari E, Bertaina A, Moretta F, Del Zotto G, Pietra G. Killer lg-like receptors (KIRs): their role in NK cell modulation and developments leading to their clinical exploitation. Front Immunol. 2019;10:1179.

40. Ljunggren H-G, Kärre K. In search of the 'missing self': MHC molecules and NK cell recognition. Immunol Today. 1990;11:237-44.

41. Kim S, Poursine-Laurent J, Truscott SM, Lybarger L, Song Y-J, Yang L, French AR, Sunwoo JB, Lemieux S, Hansen TH. Licensing of natural killer cells by host major histocompatibility complex class I molecules. Nature. 2005:436(7051):709-13.

42. Anfossi N, André P, Guia S, Falk CS, Roetynck S, Stewart CA, Breso V, Frassati C, Reviron D, Middleton D. Human NK cell education by inhibitory receptors for MHC class I. Immunity. 2006;25(2):331-42.

43. Smyth MJ, Cretney E, Kelly JM, Westwood JA, Street SE, Yagita H, Takeda K, van Dommelen SL, Degli-Esposti MA, Hayakawa Y. Activation of NK cell cytotoxicity. Mol Immunol. 2005;42(4):501-10.

44. Gómez Román VR, Murray JC, Weiner LM. Chapter 1-Antibody-dependent cellular cytotoxicity (ADCC). Antibody Fc 2014:1-27.

45. Thomas R, Yang X. NK-DC crosstalk in immunity to microbial infection. J Immunol Res. 2016;2016:6374379. 
46. Zhou Z, Zhang C, Zhang J, Tian Z. Macrophages help NK cells to attack tumor cells by stimulatory NKG2D ligand but protect themselves from NK killing by inhibitory ligand Qa-1. PLoS ONE. 2012;7(5):e36928.

47. Lion E, Willemen Y, Berneman Z, Van Tendeloo V, Smits E. Natural killer cell immune escape in acute myeloid leukemia. Leukemia. 2012;26(9):2019-26.

48. Costello RT, Sivori S, Marcenaro E, Lafage-Pochitaloff M, Mozziconacci M-J, Reviron D, Gastaut J-A, Pende D, Olive D, Moretta A. Defective expression and function of natural killer cell-triggering receptors in patients with acute myeloid leukemia. Blood. 2002;99(10):3661-7.

49. Fauriat C, Just-Landi S, Mallet F, Arnoulet C, Sainty D, Olive D, Costello RT. Deficient expression of NCR in NK cells from acute myeloid leukemia: evolution during leukemia treatment and impact of leukemia cells in NCRdull phenotype induction. Blood. 2007;109(1):323-30.

50. Sandoval-Borrego D, Moreno-Lafont MC, Vazquez-Sanchez EA, Gutierrez-Hoya A, López-Santiago R, Montiel-Cervantes LA, Ramírez-Saldaña $M$, Vela-Ojeda J. Overexpression of CD158 and NKG2A inhibitory receptors and underexpression of NKG2D and NKp46 activating receptors on NK cells in acute myeloid leukemia. Arch Med Res. 2016;47(1):55-64.

51. Stringaris K, Sekine T, Khoder A, Alsuliman A, Razzaghi B, Sargeant R, Pavlu J, Brisley G, de Lavallade H, Sarvaria A. Leukemia-induced phenotypic and functional defects in natural killer cells predict failure to achieve remission in acute myeloid leukemia. Haematologica. 2014;99(5):836-47.

52. Sanchez-Correa B, Gayoso I, Bergua JM, Casado JG, Morgado S, Solana $\mathrm{R}$, Tarazona R. Decreased expression of DNAM-1 on NK cells from acute myeloid leukemia patients. Immunol Cell Biol. 2012;90(1):109-15.

53. Coles S, Wang ECY, Man S, Hills RK, Burnett AK, Tonks A, Darley RL. CD200 expression suppresses natural killer cell function and directly inhibits patient anti-tumor response in acute myeloid leukemia. Leukemia. 2011;25(5):792-9.

54. Hilpert J, Grosse-Hovest L, Grünebach F, Buechele C, Nuebling T, Raum T, Steinle A, Salih HR. Comprehensive analysis of NKG2D ligand expression and release in leukemia: implications for NKG2D-mediated NK cell responses. J Immunol. 2012;189(3):1360-71.

55. Nowbakht P, lonescu MCS, Rohner A, Kalberer CP, Rossy E, Mori L, Cosman D, De Libero G, Wodnar-Filipowicz A. Ligands for natural killer cell-activating receptors are expressed upon the maturation of normal myelomonocytic cells but at low levels in acute myeloid leukemias. Blood. 2005;105(9):3615-22.

56. Kearney CJ, Ramsbottom KM, Voskoboinik I, Darcy PK, Oliaro J. Loss of DNAM-1 ligand expression by acute myeloid leukemia cells renders them resistant to NK cell killing. Oncoimmunology. 2016;5(8):e1196308.

57. Baragaño Raneros A, Martín-Palanco V, Fernandez AF, Rodriguez RM, Fraga MF, Lopez-Larrea C, Suarez-Alvarez B. Methylation of NKG2D ligands contributes to immune system evasion in acute myeloid leukemia. Genes Immun. 2015;16(1):71-82.

58. Salih HR, Antropius H, Gieseke F, Lutz SZ, Kanz L, Rammensee HG, Steinle A. Functional expression and release of ligands for the activating immunoreceptor NKG2D in leukemia. Blood. 2003;102(4):1389-96.

59. Yang H, Bueso-Ramos C, DiNardo C, Estecio MR, Davanlou M, Geng Q-R, Fang Z, Nguyen M, Pierce S, Wei Y. Expression of PD-L1, PD-L2, PD-1 and CTLA4 in myelodysplastic syndromes is enhanced by treatment with hypomethylating agents. Leukemia. 2014;28(6):1280-8.

60. Vitale M, Cantoni C, Pietra G, Mingari MC, Moretta L. Effect of tumor cells and tumor microenvironment on NK-cell function. Eur J Immunol. 2014;44(6):1582-92.

61. Curran EK, Godfrey J, Kline J. Mechanisms of immune tolerance in leukemia and lymphoma. Trends Immunol. 2017;38(7):513-25.

62. Tajima F, Kawatani T, Endo A, Kawasaki H. Natural killer cell activity and cytokine production as prognostic factors in adult acute leukemia. Leukemia. 1996;10(3):478.

63. Chretien A-S, Fauriat C, Orlanducci F, Galseran C, Rey J, Bouvier Borg G, Gautherot E, Granjeaud S, Hamel-Broza J-F, Demerle C. Natural killer defective maturation is associated with adverse clinical outcome in patients with acute myeloid leukemia. Front Immunol. 2017;8:573.

64. Mastaglio S, Wong E, Perera T, Ripley J, Blombery P, Smyth MJ, Koldej R, Ritchie D. Natural killer receptor ligand expression on acute myeloid leukemia impacts survival and relapse after chemotherapy. Blood Adv. 2018;2(4):335-46.
65. Martner A, Rydström A, Riise RE, Aurelius J, Anderson H, Brune M, Foà R, Hellstrand K, Thorén FB, Re: Mission Study G. Role of natural killer cell subsets and natural cytotoxicity receptors for the outcome of immunotherapy in acute myeloid leukemia. Oncoimmunology. 2016;5(1):e1041701.

66. Martner A, Rydström A, Riise RE, Aurelius J, Brune M, Foà R, Hellstrand K, Thorén FB. NK cell expression of natural cytotoxicity receptors may determine relapse risk in older AML patients undergoing immunotherapy for remission maintenance. Oncotarget. 2015;6(40):42569-74.

67. Dauguet N, Récher C, Demur C, Fournié JJ, Poupot M, Poupot R. Preeminence and persistence of immature natural killer cells in acute myeloid leukemia patients in first complete remission. Am J Hematol. 2011;86(2):209-13.

68. Ruggeri L, Capanni M, Casucci M, Volpi I, Tosti A, Perruccio K, Urbani E, Negrin RS, Martelli MF, Velardi A. Role of natural killer cell alloreactivity in HLA-mismatched hematopoietic stem cell transplantation. Blood. 1999;94(1):333-9.

69. Ruggeri L, Capanni M, Urbani E, Perruccio K, Shlomchik WD, Tosti A, Posati S, Rogaia D, Frassoni F, Aversa F. Effectiveness of donor natural killer cell alloreactivity in mismatched hematopoietic transplants. Science. 2002;295(5562):2097-100.

70. Ruggeri L, Mancusi A, Perruccio K, Burchielli E, Martelli MF, Velardi A. Natural killer cell alloreactivity for leukemia therapy. J Immunother. 2005;28(3):175-82.

71. Chan YLT, Zuo J, Inman C, Croft W, Begum J, Croudace J, Kinsella F, Maggs L, Nagra S, Nunnick J. NK cells produce high levels of IL-10 early after allogeneic stem cell transplantation and suppress development of acute GVHD. Eur J Immunol. 2018;48(2):316-29.

72. Ruggeri L, Mancusi A, Capanni M, Urbani E, Carotti A, Aloisi T, Stern M, Pende D, Perruccio K, Burchielli E. Donor natural killer cell allorecognition of missing self in haploidentical hematopoietic transplantation for acute myeloid leukemia: challenging its predictive value. Blood. 2007;110(1):433-40.

73. Cooley S, Weisdorf DJ, Guethlein LA, Klein JP, Wang T, Le CT, Marsh SG, Geraghty D, Spellman S, Haagenson MD, Ladner M, Trachtenberg E, Parham P, Miller JS. Donor selection for natural killer cell receptor genes leads to superior survival after unrelated transplantation for acute myelogenous leukemia. Blood. 2010;116(14):2411-9.

74. Stringaris K, Adams S, Uribe M, Eniafe R, Wu CO, Savani BN, Barrett AJ. Donor KIR Genes 2DL5A, 2DS1 and 3DS1 are associated with a reduced rate of leukemia relapse after HLA-identical sibling stem cell transplantation for acute myeloid leukemia but not other hematologic malignancies. Biol Blood Marrow Transplant. 2010;16(9):1257-64.

75. Miller JS, Cooley S, Parham P, Farag SS, Verneris MR, McQueen KL, Guethlein LA, Trachtenberg EA, Haagenson M, Horowitz MM. Missing KIR ligands are associated with less relapse and increased graft-versushost disease (GVHD) following unrelated donor allogeneic HCT. Blood. 2007;109(11):5058-61.

76. Savani BN, Mielke S, Adams S, Uribe M, Rezvani K, Yong AS, Zeilah J, Kurlander R, Srinivasan R, Childs R, Hensel N, Barrett AJ. Rapid natural killer cell recovery determines outcome after T-cell-depleted HLA-identical stem cell transplantation in patients with myeloid leukemias but not with acute lymphoblastic leukemia. Leukemia. 2007;21(10):2145-52.

77. Pittari G, Fregni G, Roguet L, Garcia A, Vataire A, Wittnebel S, Amsellem S, Chouaib S, Bourhis J, Caignard A. Early evaluation of natural killer activity in post-transplant acute myeloid leukemia patients. Bone Marrow Transplant. 2010;45(5):862-71.

78. Cichocki F, Cooley S, Davis Z, DeFor TE, Schlums H, Zhang B, Brunstein CG, Blazar BR, Wagner J, Diamond DJ. CD56 dim CD57+ NKG2C+ NK cell expansion is associated with reduced leukemia relapse after reduced intensity HCT. Leukemia. 2016;30(2):456-63.

79. Michelis FV, Messner HA, Loach D, Uhm J, Gupta V, Lipton JH, Seftel MD, Kuruvilla J, Kim DD. Early lymphocyte recovery at 28 d post-transplant is predictive of reduced risk of relapse in patients with acute myeloid leukemia transplanted with peripheral blood stem cell grafts. Eur J Haematol. 2014;93(4):273-80.

80. Passweg JR, Tichelli A, Meyer-Monard S, Heim D, Stern M, Kühne T, Favre G, Gratwohl A. Purified donor NK-lymphocyte infusion to consolidate engraftment after haploidentical stem cell transplantation. Leukemia. 2004;18(11):1835-8. 
81. Choi I, Yoon SR, Park S-Y, Kim H, Jung S-J, Jang YJ, Kang M, Yeom YI, Lee J-L, Kim D-Y. Donor-derived natural killer cells infused after human leukocyte antigen-haploidentical hematopoietic cell transplantation: a dose-escalation study. Biol Blood Marrow Transplant. 2014;20(5):696-704

82. Ciurea SO, Schafer JR, Bassett R, Denman CJ, Cao K, Willis D, Rondon G, Chen J, Soebbing D, Kaur I, Gulbis A, Ahmed S, Rezvani K, Shpall EJ, Lee DA, Champlin RE. Phase 1 clinical trial using mblL21 ex vivo-expanded donor-derived NK cells after haploidentical transplantation. Blood. 2017;130(16):1857-68.

83. Choi I, Yoon SR, Park S-Y, Kim H, Jung S-J, Kang Y-L, Lee J-H, Lee J-H, Kim D-Y, Lee J-L. Donor-derived natural killer cell infusion after human leukocyte antigen-haploidentical hematopoietic cell transplantation in patients with refractory acute leukemia. Biol Blood Marrow Transplant. 2016;22(11):2065-76.

84. Rubnitz JE, Inaba H, Kang G, Gan K, Hartford C, Triplett BM, Dallas M, Shook D, Gruber T, Pui CH, Leung W. Natural killer cell therapy in children with relapsed leukemia. Pediatr Blood Cancer. 2015;62(8):1468-72.

85. Yoon SR, Lee Y, Yang S, Ahn K, Lee J-H, Lee J-H, Kim D, Kang Y, Jeon M, Seol M. Generation of donor natural killer cells from CD34+ progenitor cells and subsequent infusion after HLA-mismatched allogeneic hematopoietic cell transplantation: a feasibility study. Bone Marrow Transplant. 2010;45(6):1038-46.

86. Stern M, Passweg JR, Meyer-Monard S, Esser R, Tonn T, Soerensen J, Paulussen M, Gratwohl A, Klingebiel T, Bader P. Pre-emptive immunotherapy with purified natural killer cells after haploidentical SCT: a prospective phase II study in two centers. Bone Marrow Transplant. 2013;48(3):433-8.

87. Lee DA, Denman CJ, Rondon G, Woodworth G, Chen J, Fisher T, Kaur I, Fernandez-Vina M, Cao K, Ciurea S. Haploidentical natural killer cells infused before allogeneic stem cell transplantation for myeloid malignancies: a phase I trial. Biol Blood Marrow Transplant. 2016;22(7):1290-8.

88. Miller JS, Soignier Y, Panoskaltsis-Mortari A, McNearney SA, Yun GH, Fautsch SK, McKenna D, Le C, Defor TE, Burns LJ. Successful adoptive transfer and in vivo expansion of human haploidentical NK cells in patients with cancer. Blood. 2005;105(8):3051-7.

89. Curti A, Ruggeri L, D'Addio A, Bontadini A, Dan E, Motta MR, Trabanelli S, Giudice V, Urbani E, Martinelli G. Successful transfer of alloreactive haploidentical KIR ligand-mismatched natural killer cells after infusion in elderly high risk acute myeloid leukemia patients. Blood. 2011;118(12):3273-9.

90. Björklund AT, Carlsten M, Sohlberg E, Liu LL, Clancy T, Karimi M, Cooley S, Miller JS, Klimkowska M, Schaffer M. Complete remission with reduction of high-risk clones following haploidentical NK-cell therapy against MDS and AML. Clin Cancer Res. 2018;24(8):1834-44.

91. Rubnitz JE, Inaba H, Ribeiro RC, Pounds S, Rooney B, Bell T, Pui C-H, Leung W. NKAML: a pilot study to determine the safety and feasibility of haploidentical natural killer cell transplantation in childhood acute myeloid leukemia. J Clin Oncol. 2010;28(6):955.

92. Curti A, Ruggeri L, Parisi S, Bontadini A, Dan E, Motta MR, Rizzi S, Trabanelli S, Ocadlikova D, Lecciso M. Larger size of donor alloreactive NK cell repertoire correlates with better response to NK cell immunotherapy in elderly acute myeloid leukemia patients. Clin Cancer Res. 2016;22(8):1914-21.

93. Shaffer BC, Le Luduec J-B, Forlenza C, Jakubowski AA, Perales M-A, Young JW, Hsu KC. Phase II study of haploidentical natural killer cell infusion for treatment of relapsed or persistent myeloid malignancies following allogeneic hematopoietic cell transplantation. Biol Blood Marrow Transplant. 2016;22(4):705-9.

94. Wang CJ, Huang XJ, Gong LZ, Jia JS, Liu XH, Wang Y, Yan CH, Chang YJ, Zhao XS, Shi HX, Lai YY, Jiang H. Observation on the efficacy of consolidation chemotherapy combined with allogeneic natural killer cell infusion in the treatment of low and moderate risk acute myeloid leukemia. Zhonghua Xue Ye Xue Za Zhi. 2019;40(10):812-7.

95. Nguyen R, Wu H, Pounds S, Inaba H, Ribeiro RC, Cullins D, Rooney B, Bell T, Lacayo NJ, Heym K, Degar B, Schiff D, Janssen WE, Triplett B, Pui $\mathrm{CH}$, Leung W, Rubnitz JE. A phase II clinical trial of adoptive transfer of haploidentical natural killer cells for consolidation therapy of pediatric acute myeloid leukemia. J Immunother Cancer. 2019;7(1):81.

96. Builes MM, Cuenca MV, Soler JLF, Astigarraga I, Martínez AP, Valero JMV, Tong HY, Quiroga JV, Casanova LF, López AE. Study protocol for a phase
II, multicentre, prospective, non-randomised clinical trial to assess the safety and efficacy of infusing allogeneic activated and expanded natural killer cells as consolidation therapy for paediatric acute myeloblastic leukaemia. BMJ Open. 2020;10(1):e029642.

97. Bachanova V, Cooley S, Defor TE, Verneris MR, Zhang B, McKenna DH, Curtsinger J, Panoskaltsis-Mortari A, Lewis D, Hippen K, McGlave P, Weisdorf DJ, Blazar BR, Miller JS. Clearance of acute myeloid leukemia by haploidentical natural killer cells is improved using IL-2 diphtheria toxin fusion protein. Blood. 2014;123(25):3855-63.

98. Vela M, Corral D, Carrasco P, Fernández L, Valentín J, González B, Escudero A, Balas A, de Paz R, Torres J, Leivas A, Martinez-Lopez J, PérezMartínez A. Haploidentical IL-15/41BBL activated and expanded natural killer cell infusion therapy after salvage chemotherapy in children with relapsed and refractory leukemia. Cancer Lett. 2018;422:107-17.

99. Zhao XY, Jiang Q, Jiang H, Hu LJ, Zhao T, Yu XX, Huang XJ. Expanded clinical-grade membrane-bound IL-21/4-1BBL NK cell products exhibit activity against acute myeloid leukemia in vivo. Eur J Immunol. 2020;50:1374-85.

100. Wu Y, Li Y, Fu B, Jin L, Zheng X, Zhang A, Sun R, Tian Z, Wei H. Programmed differentiated natural killer cells kill leukemia cells by engaging SLAM family receptors. Oncotarget. 2017;8(34):57024-38.

101. Oyer JL, Igarashi RY, Kulikowski AR, Colosimo DA, Solh MM, Zakari A, Khaled YA, Altomare DA, Copik AJ. Generation of highly cytotoxic natural killer cells for treatment of acute myelogenous leukemia using a feeder-free, particle-based approach. Biol Blood Marrow Transplant. 2015;21(4):632-9.

102. Fehniger TA, Miller JS, Stuart RK, Cooley S, Salhotra A, Curtsinger J, Westervelt P, DiPersio JF, Hillman TM, Silver N. A phase 1 trial of CNDO109-activated natural killer cells in patients with high-risk acute myeloid leukemia. Biol Blood Marrow Transplant. 2018;24(8):1581-9.

103. Kottaridis PD, North J, Tsirogianni M, Marden C, Samuel ER, Jide-Banwo S, Grace S, Lowdell MW. Two-stage priming of allogeneic natural killer cells for the treatment of patients with acute myeloid leukemia: a phase I trial. PLOS ONE. 2015;10(6):e0123416.

104. Tao Q, Chen T, Tao L, Wang H, Pan Y, Xiong S, Zhai Z. IL-15 improves the cytotoxicity of cytokine-induced killer cells against leukemia cells by upregulating CD3 + CD56+ cells and downregulating regulatory $T$ cells as well as IL-35. J Immunother. 2013;36(9):462-7.

105. Rettinger E, Meyer V, Kreyenberg H, Volk A, Kuçi S, Willasch A, Koscielniak E, Fulda S, Wels W, Boenig H. Cytotoxic capacity of IL-15-stimulated cytokine-induced killer cells against human acute myeloid leukemia and rhabdomyosarcoma in humanized preclinical mouse models. Front Oncol. 2012;2:32.

106. Cooley S, He F, Bachanova V, Vercellotti GM, DeFor TE, Curtsinger JM, Robertson P, Grzywacz B, Conlon KC, Waldmann TA. First-in-human trial of rhIL-15 and haploidentical natural killer cell therapy for advanced acute myeloid leukemia. Blood Adv. 2019;3(13):1970-80.

107. Grzywacz B, Moench L, McKenna D Jr, Tessier KM, Bachanova V, Cooley S, Miller JS, Courville EL. Natural killer cell homing and persistence in the bone marrow after adoptive immunotherapy correlates with better leukemia control. J Immunother (Hagerstown, Md: 1997). 2019;42(2):65.

108. Boyiadzis M, Agha M, Redner RL, Sehgal A, Im A, Hou JZ, Farah R, Dorritie KA, Raptis A, Lim SH, Wang H, Lapteva N, Mei Z, Butterfield LH, Rooney CM, Whiteside TL. Phase 1 clinical trial of adoptive immunotherapy using "off-the-shelf" activated natural killer cells in patients with refractory and relapsed acute myeloid leukemia. Cytotherapy. 2017;19(10):1225-32.

109. Huang C-H, Liao Y-J, Fan T-H, Chiou T-J, Lin Y-H, Twu Y-C. A developed NK-92Ml cell line with siglec-7neg phenotype exhibits high and sustainable cytotoxicity against leukemia cells. Int J Mol Sci. 2018;19(4):1073.

110. Cany J, van der Waart AB, Tordoir M, Franssen GM, Hangalapura BN, de Vries J, Boerman O, Schaap N, van der Voort R, Spanholtz J. Natural killer cells generated from cord blood hematopoietic progenitor cells efficiently target bone marrow-residing human leukemia cells in NOD/ SCID/IL2Rg null mice. PLoS ONE. 2013;8(6):e64384.

111. Dolstra H, Roeven MW, Spanholtz J, Hangalapura BN, Tordoir M, Maas F, Leenders M, Bohme F, Kok N, Trilsbeek C. Successful transfer of umbilical cord blood CD34+ hematopoietic stem and progenitor-derived NK cells in older acute myeloid leukemia patients. Clin Cancer Res. 2017;23(15):4107-18. 
112. Cooley S, Hari P, McCloskey J, Byrne M, Wang E, Hussein M, Giarritta E, Zhang X, Hariri R, Miller JS. Abstract CT079: a phase I study of PNK-007, allogeneic, off the shelf NK cell in relapsed/refractory AML (NCT02781467). In: AACR; 2019.

113. Cummins KD, Gill S. Chimeric antigen receptor T-cell therapy for acute myeloid leukemia: how close to reality? Haematologica. 2019;104(7):1302-8.

114. Yáñez L, Sánchez-Escamilla M, Perales M-A. CAR T cell toxicity: current management and future directions. HemaSphere. 2019;3(2):e186.

115. Klingemann H. Are natural killer cells superior CAR drivers? Oncoimmunology. 2014;3:e28147.

116. Hauswirth AW, Florian S, Printz D, Sotlar K, Krauth MT, Fritsch G, Schernthaner GH, Wacheck V, Selzer E, Sperr WR. Expression of the target receptor CD33 in CD34+/CD38-/CD123+ AML stem cells. Eur J Clin Investig. 2007;37(1):73-82

117. Schirrmann T, Pecher G. Specific targeting of CD33(+) leukemia cells by a natural killer cell line modified with a chimeric receptor. Leuk Res. 2005;29(3):301-6.

118. Tang $X$, Yang L, Li Z, Nalin AP, Dai H, Xu T, Yin J, You F, Zhu M, Shen W, Chen G, Zhu X, Wu D, Yu J. First-in-man clinical trial of CAR NK-92 cells: safety test of CD33-CAR NK-92 cells in patients with relapsed and refractory acute myeloid leukemia. Am J Cancer Res. 2018;8(6):1083-9.

119. Salman H, Pinz KG, Wada M, Shuai X, Yan LE, Petrov JC, Ma Y. Preclinical targeting of human acute myeloid leukemia using CD4-specific chimeric antigen receptor (CAR) T cells and NK cells. J Cancer. 2019;10(18):4408-19.

120. Chang H, Salma F, Yi Q, Patterson B, Brien B, Minden MD. Prognostic relevance of immunophenotyping in 379 patients with acute myeloid leukemia. Leuk Res. 2004;28(1):43-8.

121. Zhu MY, Zhu Y, Chen RR, Zhu LX, Zhu JJ, Li XY, Zhou D, Yang XD, Zheng $Y L$, Xie MX. CD7 expression and its prognostic significance in acute myeloid leukemia patients with wild-type or mutant CEBPA. Nature. 2020;41(2):100-5.

122. Zhu X-Y, Liu X, Wang X-B, Wang A-Y, Wang M, Liu N-N, You F-T, Pan G-F, Yang L. Killing effect of A CD7 chimeric antigen receptor-modified NK $92 \mathrm{Ml}$ cell line on CD7-positive hematological malignant cells. Zhongguo shi yan xue ye xue za zhi. 2020;28(4):1367-75.

123. Kloess S, Oberschmidt O, Dahlke J, Vu X-K, Neudoerfl C, Kloos A, Gardlowski T, Matthies N, Heuser M, Meyer J. Preclinical assessment of suitable natural killer cell sources for chimeric antigen receptor natural killer-based "off-the-shelf" acute myeloid leukemia immunotherapies. Hum Gene Ther. 2019;30(4):381-401.

124. He SZ, Busfield S, Ritchie DS, Hertzberg MS, Durrant S, Lewis ID, Marlton P, McLachlan AJ, Kerridge I, Bradstock KF, Kennedy G, Boyd AW, Yeadon TM, Lopez AF, Ramshaw HS, Iland H, Bamford S, Barnden M, DeWitte M, Basser R, Roberts AW. A phase 1 study of the safety, pharmacokinetics and anti-leukemic activity of the anti-CD123 monoclonal antibody CSL360 in relapsed, refractory or high-risk acute myeloid leukemia. Leuk Lymphoma. 2015;56(5):1406-15.

125. Sekeres MA, Lancet JE, Wood BL, Grove LE, Sandalic L, Sievers EL, Jurcic JG. Randomized phase Ilb study of low-dose cytarabine and lintuzumab versus low-dose cytarabine and placebo in older adults with untreated acute myeloid leukemia. Haematologica. 2013;98(1):119-28.

126. Feldman EJ, Brandwein J, Stone R, Kalaycio M, Moore J, O'Connor J, Wedel N, Roboz GJ, Miller C, Chopra R, Jurcic JC, Brown R, Ehmann WC, Schulman P, Frankel SR, De Angelo D, Scheinberg D. Phase III randomized multicenter study of a humanized anti-CD33 monoclonal antibody, lintuzumab, in combination with chemotherapy, versus chemotherapy alone in patients with refractory or first-relapsed acute myeloid leukemia. J Clin Oncol. 2005;23(18):4110-6.

127. Sallman DA, Asch AS, Al Malki MM, Lee DJ, Donnellan WB, Marcucci G, Kambhampati S, Daver NG, Garcia-Manero G, Komrokji RS. The firstin-class anti-CD47 antibody magrolimab (5F9) in combination with azacitidine is effective in MDS and AML patients: ongoing phase $1 \mathrm{~b}$ results. Blood. 2019;134(Supplement_1):569.

128. Riether $C$, Pabst T, Höpner S, Bacher U, Hinterbrandner M, Banz Y, Müller R, Manz MG, Gharib WH, Francisco D. Targeting CD70 with cusatuzumab eliminates acute myeloid leukemia stem cells in patients treated with hypomethylating agents. Nat Med. 2020;26:1-9.

129. Kayser S, Heitmann JS, Dörfel D, Thol F, Heuser M, Märklin M, MüllerTidow C, Steiner M, Grosse-Hovest L, Jung G, Schlenk RF, Salih HR.
Interim results of a first in man study with the Fc-optimized FLT3 antibody Flysyn for treatment of acute myeloid leukemia with minimal residual disease. Blood. 2019;134(Supplement_1):3928.

130. Koerner SP, André MC, Leibold JS, Kousis PC, Kübler A, Pal M, Haen SP, Bühring HJ, Grosse-Hovest L, Jung G, Salih HR. An Fc-optimized CD133 antibody for induction of NK cell reactivity against myeloid leukemia. Leukemia. 2017;31(2):459-69.

131. Vasu S, He S, Cheney C, Gopalakrishnan B, Mani R, Lozanski G, Mo X, Groh V, Whitman SP, Konopitzky R, Kössl C, Bucci D, Lucas DM, Yu J, Caligiuri MA, Blum W, Adam PJ, Borges E, Rueter B, Heider KH, Marcucci G, Muthusamy N. Decitabine enhances anti-CD33 monoclonal antibody BI 836858-mediated natural killer ADCC against AML blasts. Blood. 2016;127(23):2879-89.

132. Ågerstam H, Karlsson C, Hansen N, Sandén C, Askmyr M, von Palffy S, Högberg C, Rissler M, Wunderlich M, Juliusson G. Antibodies targeting human IL1RAP (IL1R3) show therapeutic effects in xenograft models of acute myeloid leukemia. Proc Natl Acad Sci. 2015;112(34):10786-91.

133. Venditti A, Buccisano F, Maurillo L, Del Principe MI, Coppola A, Palomba P, Arriga R, Bellarosa D, Bressan A, Wilson K. MEN1112/OBT357, an anti Bst1/CD157 humanized antibody inducing acute myelogenous leukemia (AML) blast depletion in an autologous ex vivo assay: a potential new targeted therapy for AML. Blood. 2015;126(23):788.

134. Krupka C, Lichtenegger FS, Köhnke T, Bögeholz J, Bücklein V, Roiss M, Altmann T, Do TU, Dusek R, Wilson K. Targeting CD157 in AML using a novel, Fc-engineered antibody construct. Oncotarget. 2017;8(22):35707.

135. Williams BA, Wang XH, Leyton JV, Maghera S, Deif B, Reilly RM, Minden MD, Keating A. CD16(+)NK-92 and anti-CD123 monoclonal antibody prolongs survival in primary human acute myeloid leukemia xenografted mice. Haematologica. 2018;103(10):1720-9.

136. Mani R, Rajgolikar G, Nunes J, Zapolnik K, Wasmuth R, Mo X, Byrd JC, Lee DA, Muthusamy N, Vasu S. Fc-engineered anti-CD33 monoclonal antibody potentiates cytotoxicity of membrane-bound interleukin-21 expanded natural killer cells in acute myeloid leukemia. Cytotherapy. 2020;22(7):369-76.

137. Narayan R, Blonquist TM, Emadi A, Hasserjian RP, Burke M, Lescinskas C, Neuberg DS, Brunner AM, Hobbs G, Hock H, McAfee SL, Chen YB, Attar E, Graubert TA, Bertoli C, Moran JA, Bergeron MK, Foster JE, Ramos AY, Som TT, Vartanian MK, Story JL, McGregor K, Macrae M, Behnan T, Wey MC, Rae J, Preffer FI, Lesho P, Duong VH, et al. A phase 1 study of the antibody-drug conjugate brentuximab vedotin with re-induction chemotherapy in patients with CD30-expressing relapsed/refractory acute myeloid leukemia. Cancer. 2020;126(6):1264-73.

138. Goldberg AD, Atallah E, Rizzieri D, Walter RB, Chung K-Y, Spira A, Stock W, Tallman MS, Cruz HG, Boni J. Camidanlumab tesirine, an antibodydrug conjugate, in relapsed/refractory CD25-positive acute myeloid leukemia or acute lymphoblastic leukemia: a phase I study. Leuk Res. 2020;95:106385.

139. Daver NG, Erba HP, Papadantonakis N, DeAngelo DJ, Wang ES, Konopleva MY, Sloss CM, Culm-Merdek K, Zweidler-McKay PA, Kantarjian HM. A phase I, first-in-human study evaluating the safety and preliminary antileukemia activity of IMGN632, a novel CD123-targeting antibodydrug conjugate, in patients with relapsed/refractory acute myeloid leukemia and other CD123-positive hematologic malignancies. Blood. 2018;132(Supplement_1):27.

140. Agura E, Gyurkocza B, Nath R, Litzow MR, Tomlinson BK, Abhyankar S, Seropian S, Stiff PJ, Choe HK, Kebriaei P. Targeted conditioning of lomab-B (131l-anti-CD45) prior to allogeneic hematopoietic cell transplantation versus conventional care in relapsed or refractory acute myeloid leukemia (AML): preliminary feasibility and safety results from the prospective, randomized phase 3 Sierra trial. Blood. 2018;132(Supplement_1):1017.

141. Jurcic JG, Ravandi F, Pagel JM, Park JH, Smith BD, Douer D, Levy MY, Estey E, Kantarjian HM, Earle D, Cicic D, Scheinberg DA. Phase I trial of a-particle therapy with actinium-225 (225Ac)-lintuzumab (anti-CD33) and low-dose cytarabine (LDAC) in older patients with untreated acute myeloid leukemia (AML). J Clin Oncol. 2015;33(15_suppl):7050.

142. Castaigne $S$, Pautas C, Terré C, Raffoux E, Bordessoule D, Bastie JN, Legrand O, Thomas X, Turlure P, Reman O, de Revel T, Gastaud L, de Gunzburg N, Contentin N, Henry E, Marolleau JP, Aljijakli A, Rousselot P, Fenaux P, Preudhomme C, Chevret S, Dombret H. Effect of gemtuzumab ozogamicin on survival of adult patients with de-novo acute 
myeloid leukaemia (ALFA-0701): a randomised, open-label, phase 3 study. Lancet. 2012;379(9825):1508-16.

143. Amadori S, Suciu S, Selleslag D, Aversa F, Gaidano G, Musso M, Annino L, Venditti A, Voso MT, Mazzone C. Gemtuzumab ozogamicin versus best supportive care in older patients with newly diagnosed acute myeloid leukemia unsuitable for intensive chemotherapy: results of the randomized phase III EORTC-GIMEMA AML-19 trial. J Clin Oncol. 2016;34(9):972-9.

144. Taksin AL, Legrand O, Raffoux E, de Revel T, Thomas X, Contentin N, Bouabdallah R, Pautas C, Turlure P, Reman O, Gardin C, Varet B, de Botton S, Pousset F, Farhat H, Chevret S, Dombret H, Castaigne S. High efficacy and safety profile of fractionated doses of Mylotarg as induction therapy in patients with relapsed acute myeloblastic leukemia: a prospective study of the alfa group. Leukemia. 2007;21(1):66-71.

145. Pereira DS, Guevara Cl, Jin L, Mbong N, Verlinsky A, Hsu SJ, Aviña H, Karki S, Abad JD, Yang P. AGS67E, an anti-CD37 monomethyl auristatin E antibody-drug conjugate as a potential therapeutic for B/T-cell malignancies and AML: a new role for CD37 in AML. Mol Cancer Ther. 2015;14(7):1650-60.

146. Zheng B, Yu S-F, Del Rosario G, Leong SR, Lee GY, Vij R, Chiu C, Liang W-C, Wu Y, Chalouni C. An anti-CLL-1 antibody-drug conjugate for the treatment of acute myeloid leukemia. Clin Cancer Res. 2019;25(4):1358-68.

147. Jiang Y-P, Liu BY, Zheng Q, Panuganti S, Chen R, Zhu J, Mishra M, Huang J, Dao-Pick T, Roy S. CLT030, a leukemic stem cell-targeting CLL1 antibody-drug conjugate for treatment of acute myeloid leukemia. Blood Adv. 2018;2(14):1738-49.

148. Anami Y, Deng M, Gui X, Yamaguchi A, Yamazaki CM, Zhang N, Zhang C, An Z, Tsuchikama K. LILRB4-targeting antibody-drug conjugates for the treatment of acute myeloid leukemia. Mol Cancer Ther. 2020;19:2330-9.

149. Li F, Sutherland MK, Yu C, Walter RB, Westendorf L, Valliere-Douglass J, Pan L, Cronkite A, Sussman D, Klussman K. Characterization of SGNCD123A, a potent CD123-directed antibody-drug conjugate for acute myeloid leukemia. Mol Cancer Ther. 2018;17(2):554-64.

150. Snyder JT, Malinao M-C, Dugal-Tessier J, Atkinson JE, Anand BS, Okada A, Mendelsohn BA. Metabolism of an oxime-linked antibody drug conjugate, AGS62P1, and characterization of its identified metabolite. Mol Pharm. 2018;15(6):2384-90.

151. Kovtun Y, Noordhuis P, Whiteman KR, Watkins K, Jones GE, Harvey L, Lai KC, Portwood S, Adams S, Sloss CM. IMGN779, a novel CD33targeting antibody-drug conjugate with DNA-alkylating activity, exhibits potent antitumor activity in models of AML. Mol Cancer Ther. 2018;17(6):1271-9.

152. Chan WK, Kung Sutherland M, Li Y, Zalevsky J, Schell S, Leung W. Antibody-dependent cell-mediated cytotoxicity overcomes NK cell resistance in MLL-rearranged leukemia expressing inhibitory KIR ligands but not activating ligands. Clin Cancer Res. 2012;18(22):6296-305.

153. Brodská B, Otevřelová P, Šálek C, Fuchs O, Gašová Z, Kuželová K. High PD-L1 expression predicts for worse outcome of leukemia patients with concomitant NPM1 and FLT3 mutations. Int J Mol Sci. 2019;20(11):2823.

154. Yang H, Bueso-Ramos CE, Parmar S, Wei Y, Fang Z, Nguyen M, Fernandez M, Pierce SA, Geng Q, Kantarjian HM. Induction of PD-1 and PD-1 ligand expression by hypomethylating agents (HMA) in myelodysplastic syndromes and acute myelogenous leukemia suggest a role for T cell function in clinical resistance to Hmas. Blood. 2012;120(21):3810.

155. Daver N, Boddu P, Garcia-Manero G, Yadav SS, Sharma P, Allison J, Kantarjian H. Hypomethylating agents in combination with immune checkpoint inhibitors in acute myeloid leukemia and myelodysplastic syndromes. Leukemia. 2018;32(5):1094-105.

156. Schmiedel BJ, Werner A, Steinbacher J, Nuebling T, Buechele C, GrosseHovest L, Salih HR. Generation and preclinical characterization of a Fc-optimized GITR-Ig fusion protein for induction of NK cell reactivity against leukemia. Mol Ther. 2013;21(4):877-86.

157. Schmiedel BJ, Nuebling T, Steinbacher J, Malinovska A, Wende CM, Azuma M, Schneider P, Grosse-Hovest L, Salih HR. Receptor activator for NF-kB ligand in acute myeloid leukemia: expression, function, and modulation of NK cell immunosurveillance. J Immunol. 2013;190(2):821-31.

158. Baessler T, Krusch M, Schmiedel BJ, Kloss M, Baltz KM, Wacker A, Schmetzer HM, Salih HR. Glucocorticoid-induced tumor necrosis factor receptor-related protein ligand subverts immunosurveillance of acute myeloid leukemia in humans. Cancer Res. 2009;69(3):1037-45.

159. Steinbacher J, Baltz-Ghahremanpour K, Schmiedel BJ, Steinle A, Jung G, Kübler A, André MC, Grosse-Hovest L, Salih HR. An Fcoptimized NKG2D-immunoglobulin G fusion protein for induction of natural killer cell reactivity against leukemia. Int J Cancer. 2015;136(5):1073-84.

160. Deng G, Zheng X, Zhou J, Wei H, Tian Z, Sun R. Generation and preclinical characterization of an NKp80-Fc fusion protein for redirected cytolysis of natural killer (NK) cells against leukemia. J Biol Chem. 2015;290(37):22474-84.

161. Khan M, Arooj S, Wang H. NK cell-based immune checkpoint inhibition. Front Immunol. 2020;1 1:167.

162. Vey N, Bourhis JH, Boissel N, Bordessoule D, Prebet T, Charbonnier A, Etienne A, Andre P, Romagne F, Benson D, Dombret H, Olive D. A phase 1 trial of the anti-inhibitory KIR mAb IPH2101 for AML in complete remission. Blood. 2012;120(22):4317-23.

163. Vey N, Bourhis J-H, Recher C, Etienne A, Charbonnier A, Rey J, André P, Calmels F, Zerbib R, Buffet R. Repeated dosing of anti-KIR (IPH2101) as maintenance therapy in elderly patients with acute myeloid leukemia. Blood. 2013;122(21):2696.

164. Vey N, Dumas P-Y, Recher C, Gastaud L, Lioure B, Bulabois C-E, Pautas C, Marolleau J-P, Leprêtre S, Raffoux E, Thomas X, Hicheri Y, Bonmati C, Quesnel B, Rousselot P, Castaigne S, Jourdan E, Malfuson JV, Guillerm G, Bouhris JH, Ojeda M, Hunault M, Ifrah N, Gardin C, Delannoy A, Beautier L, Paturel C, Andre P, Zerbib R, Preudhomme C, et al. Randomized phase 2 trial of lirilumab (anti-KIR monoclonal antibody, $\mathrm{mAb}$ ) as maintenance treatment in elderly patients (pts) with acute myeloid leukemia (AML): results of the Effikir trial. Blood. 2017;130(Supplement_1):889.

165. Daver NG, Garcia-Manero G, Cortes JE, Basu S, Ravandi F, Kadia TM, Borthakur G, Jabbour E, Dinardo CD, Pemmaraju N. Phase IB/ II study of lirilumab with azacytidine (AZA) in relapsed AML. Blood. 2017;130(Supplement_1):2634.

166. Godal R, Bachanova V, Gleason M, McCullar V, Yun GH, Cooley S, Verneris MR, McGlave PB, Miller JS. Natural killer cell killing of acute myelogenous leukemia and acute lymphoblastic leukemia blasts by killer cell immunoglobulin-like receptor-negative natural killer cells after NKG2A and LIR-1 blockade. Biol Blood Marrow Transplant. 2010;16(5):612-21.

167. Ruggeri L, Urbani E, André P, Mancusi A, Tosti A, Topini F, Bléry M, Animobono L, Romagné F, Wagtmann N, Velardi A. Effects of anti-NKG2A antibody administration on leukemia and normal hematopoietic cells. Haematologica. 2016;101(5):626-33.

168. Ravandi F, Assi R, Daver N, Benton CB, Kadia T, Thompson PA, Borthakur G, Alvarado Y, Jabbour EJ, Konopleva M. Idarubicin, cytarabine, and nivolumab in patients with newly diagnosed acute myeloid leukaemia or high-risk myelodysplastic syndrome: a single-arm, phase 2 study. Lancet Haematol. 2019;6(9):e480-8.

169. Daver N, Garcia-Manero G, Basu S, Boddu PC, Alfayez M, Cortes JE, Konopleva M, Ravandi-Kashani F, Jabbour E, Kadia T. Efficacy, safety, and biomarkers of response to azacitidine and nivolumab in relapsed/ refractory acute myeloid leukemia: a nonrandomized, open-label, phase II study. Cancer Discov. 2019;9(3):370-83.

170. Daver NG, Garcia-Manero G, Konopleva MY, Alfayez M, Pemmaraju N, Kadia TM, DiNardo CD, Cortes JE, Ravandi F, Abbas H. Azacitidine (AZA) with nivolumab (Nivo), and AZA with Nivo+ ipilimumab (Ipi) in relapsed/refractory acute myeloid leukemia: a non-randomized, prospective, phase 2 study. Blood. 2019;134(Supplement_1):830.

171. Kadia TM, Cortes JE, Ghorab A, Ravandi F, Jabbour E, Daver NG, Alvarado Y, Ohanian M, Konopleva M, Kantarjian HM. Nivolumab (Nivo) maintenance (maint) in high-risk (HR) acute myeloid leukemia (AML) patients. J Clin Oncol. 2018;36:7014.

172. Lindblad KE, Thompson J, Gui G, Valdez J, Worthy T, Tekleab H, Hughes T, Goswami M, Oetjen K, Kim D-Y, Dillon L, DeStefano C, Lai CE, Hourigan CS. Pembrolizumab and decitabine for refractory or relapsed acute myeloid leukemia. Blood. 2018;132(Supplement_1):1437.

173. Zeidner JF, Vincent BG, Esparza S, Ivanova A, Moore DT, Foster MC, Coombs CC, Jamieson K, Van Deventer HW, Blanchard L. Final clinical results of a phase II study of high dose cytarabine followed by pembrolizumab in relapsed/refractory AML. Blood. 2019;134(Supplement_1):831. 
174. Davids MS, Kim HT, Bachireddy P, Costello C, Liguori R, Savell A, Lukez AP, Avigan D, Chen Y-B, McSweeney P. I pilimumab for patients with relapse after allogeneic transplantation. N Engl J Med. 2016;375:143-53.

175. Borate U, Esteve J, Porkka K, Knapper S, Vey N, Scholl S, Garcia-Manero G, Wermke M, Janssen J, Traer E, Chua CC, Narayan R, Tovar N, Kontro M, Ottmann O, Sun H, Longmire T, Szpakowski S, Liao S, Patel A, Rinne ML, Brunner A, Wei AH. Phase lb study of the anti-TIM-3 antibody MBG453 in combination with decitabine in patients with high-risk myelodysplastic syndrome (MDS) and acute myeloid leukemia (AML). Blood. 2019;134(Supplement_1):570.

176. Gros F, Cazaubiel T, Forcade E, Lechevalier N, Leguay T, Servant V, Tabrizi R, Clement L, Dumas P, Bidet A. Severe acute GvHD following administration of ipilimumab for early relapse of AML after haploidentical stem cell transplantation. Bone Marrow Transplant. 2017;52(7):1047-8.

177. Ijaz A, Khan AY, Malik SU, Faridi W, Fraz MA, Usman M, Tariq MJ, Durer S, Durer C, Russ A. Significant risk of graft-versus-host disease with exposure to checkpoint inhibitors before and after allogeneic transplantation. Biol Blood Marrow Transplant. 2019:25(1):94-9.

178. Baessler T, Charton JE, Schmiedel BJ, Grünebach F, Krusch M, Wacker A, Rammensee HG, Salih HR. CD137 ligand mediates opposite effects in human and mouse NK cells and impairs NK-cell reactivity against human acute myeloid leukemia cells. Blood. 2010;115(15):3058-69.

179. Hattori N, Kawaguchi Y, Sasaki Y, Shimada S, Murai S, Abe M, Baba Y, Watanuki M, Fujiwara S, Arai N. Monitoring TIGIT/DNAM-1 and PVR/ PVRL2 immune checkpoint expression levels in allogeneic stem cell transplantation for acute myeloid leukemia. Biol Blood Marrow Transplant. 2019;25(5):861-7.

180. Atfy M, Ebian HF, Elshorbagy SM, Atteia HH. CD200 suppresses the natural killer cells and decreased its activity in acute myeloid leukemia patients. J Leukemia. 2015;3:1-5.

181. Gleason MK, Verneris MR, Todhunter DA, Zhang B, McCullar V, Zhou SX, Panoskaltsis-Mortari A, Weiner LM, Vallera DA, Miller JS. Bispecific and trispecific killer cell engagers directly activate human NK cells through CD16 signaling and induce cytotoxicity and cytokine production. Mol Cancer Ther. 2012;11(12):2674-84.

182. Wiernik A, Foley B, Zhang B, Verneris MR, Warlick E, Gleason MK, Ross JA, Luo X, Weisdorf DJ, Walcheck B, Vallera DA, Miller JS. Targeting natural killer cells to acute myeloid leukemia in vitro with a CD16 × 33 bispecific killer cell engager and ADAM17 inhibition. Clin Cancer Res. 2013;19(14):3844-55.

183. Vallera DA, Felices M, McElmurry R, McCullar V, Zhou X, Schmohl JU, Zhang B, Lenvik AJ, Panoskaltsis-Mortari A, Verneris MR. IL15 trispecific killer engagers (TrikE) make natural killer cells specific to CD33+ targets while also inducing persistence, in vivo expansion, and enhanced function. Clin Cancer Res. 2016;22(14):3440-50.

184. Singer $\mathrm{H}$, Kellner $\mathrm{C}$, Lanig $\mathrm{H}$, Aigner M, Stockmeyer B, Oduncu F, Schwemmlein M, Stein C, Mentz K, Mackensen A, Fey GH. Effective elimination of acute myeloid leukemic cells by recombinant bispecific antibody derivatives directed against CD33 and CD16. J Immunother. 2010;33(6):599-608

185. Kügler M, Stein C, Kellner C, Mentz K, Saul D, Schwenkert M, Schubert I, Singer H, Oduncu F, Stockmeyer B, Mackensen A, Fey GH. A recombinant trispecific single-chain Fv derivative directed against CD123 and CD33 mediates effective elimination of acute myeloid leukaemia cells by dual targeting. Br J Haematol. 2010;150(5):574-86.

186. Märklin M, Hagelstein I, Koerner SP, Rothfelder K, Pfluegler MS, Schumacher A, Grosse-Hovest L, Jung G, Salih HR. Bispecific NKG2D-CD3 and NKG2D-CD16 fusion proteins for induction of NK and T cell reactivity against acute myeloid leukemia. J Immunother Cancer. 2019;7(1):143.

187. Arvindam US, van Hauten PMM, Schirm D, Schaap N, Hobo W, Blazar BR, Vallera DA, Dolstra H, Felices M, Miller JS. A trispecific killer engager molecule against CLEC12A effectively induces NK-cell mediated killing of AML cells. Leukemia. 2020. https://doi.org/10.1038/s41375-02001065-5.

188. Decot V, Voillard L, Latger-Cannard V, Aissi-Rothé L, Perrier P, Stoltz JF, Bensoussan D. Natural-killer cell amplification for adoptive leukemia relapse immunotherapy: comparison of three cytokines, IL-2, IL-15, or IL-7 and impact on NKG2D, KIR2DL1, and KIR2DL2 expression. Exp Hematol. 2010;38(5):351-62.

189. Szczepanski MJ, Szajnik M, Welsh A, Foon KA, Whiteside TL, Boyiadzis M. Interleukin-15 enhances natural killer cell cytotoxicity in patients with acute myeloid leukemia by upregulating the activating NK cell receptors. Cancer Immunol Immunother. 2010;59(1):73.

190. Sanchez-Correa B, Bergua JM, Pera A, Campos C, Arcos MJ, Bañas H, Duran E, Solana R, Tarazona R. In vitro culture with interleukin-15 leads to expression of activating receptors and recovery of natural killer cell function in acute myeloid leukemia patients. Front Immunol. 2017;8:931.

191. Baer MR, George SL, Caligiuri MA, Sanford BL, Bothun SM, Mrózek K, Kolitz JE, Powell BL, Moore JO, Stone RM. Low-dose interleukin-2 immunotherapy does not improve outcome of patients age 60 years and older with acute myeloid leukemia in first complete remission: cancer and Leukemia Group B Study 9720. J Clin Oncol. 2008;26(30):4934.

192. Lange BJ, Smith FO, Feusner J, Barnard DR, Dinndorf P, Feig S, Heerema NA, Arndt C, Arceci RJ, Seibel N. Outcomes in CCG-2961, a children's oncology group phase 3 trial for untreated pediatric acute myeloid leukemia: a report from the children's oncology group. Blood. 2008;111(3):1044-53.

193. Petit A, Ducassou S, Leblanc T, Pasquet M, Rousseau A, Ragu C, Cachanado M, Nelken B, Bertrand Y, Michel G. Maintenance therapy with interleukin-2 for childhood AML: results of ELAM02 phase III randomized trial. HemaSphere. 2018;2(6):e159.

194. Pautas C, Merabet F, Thomas X, Raffoux E, Gardin C, Corm S, Bourhis $\mathrm{J}-\mathrm{H}$, Reman O, Turlure P, Contentin N. Randomized study of intensified anthracycline doses for induction and recombinant interleukin-2 for maintenance in patients with acute myeloid leukemia age 50 to 70 years: results of the ALFA-9801 study. J Clin Oncol. 2010;28(5):808-14.

195. Brune M, Castaigne S, Catalano J, Gehlsen K, Ho AD, Hofmann W-K, Hogge DE, Nilsson B, Or R, Romero Al. Improved leukemia-free survival after postconsolidation immunotherapy with histamine dihydrochloride and interleukin-2 in acute myeloid leukemia: results of a randomized phase 3 trial. Blood. 2006;108(1):88-96.

196. Nilsson MS, Hallner A, Brune M, Nilsson S, Thorén FB, Martner A, Hellstrand K. Immunotherapy with HDC/IL-2 may be clinically efficacious in acute myeloid leukemia of normal karyotype. Hum Vaccines Immunother. 2020;16(1):109-11.

197. Cuapio A, Post M, Cerny-Reiterer S, Gleixner KV, Stefanzl G, Basilio J, Herndlhofer S, Sperr WR, Brons NH, Casanova E. Maintenance therapy with histamine plus IL-2 induces a striking expansion of two CD56bright NK cell subpopulations in patients with acute myeloid leukemia and supports their activation. Oncotarget. 2016;7(29):46466

198. Romee R, Cooley S, Berrien-Elliott MM, Westervelt P, Verneris MR, Wagner JE, Weisdorf DJ, Blazar BR, Ustun C, DeFor TE. First-in-human phase 1 clinical study of the IL-15 superagonist complex ALT-803 to treat relapse after transplantation. Blood. 2018;131(23):2515-27.

199. Huang J, Liu Y, Au BC, Barber DL, Arruda A, Schambach A, Rothe M, Minden MD, Paige CJ, Medin JA. Preclinical validation: LV/LL-12 transduction of patient leukemia cells for immunotherapy of AML. Mol Therapy Methods Clin Dev. 2016;3:16074.

200. Shi Y, Dincheva-Vogel L, Ayemoba CE, Fung JP, Bergamaschi C, Pavlakis GN, Farzaneh F, Gaensler KML. IL-15/IL-15Ra/CD80-expressing AML cell vaccines eradicate minimal residual disease in leukemic mice. Blood Adv. 2018;2(22):3177-92.

201. Cooper MA, Yokoyama WM. Memory-like responses of natural killer cells. Immunol Rev. 2010;235(1):297-305.

202. Romee R, Schneider SE, Leong JW, Chase JM, Keppel CR, Sullivan RP, Cooper MA, Fehniger TA. Cytokine activation induces human memorylike NK cells. Blood. 2012;120(24):4751-60.

203. Rosario M, Romee R, Schneider SE, Leong JW, Sullivan RP, Fehniger TA. Human cytokine-induced memory-like (CIML) NK cells are active against myeloid leukemia in vitro and in vivo. Blood. 2014;124(21):1117.

204. Romee R, Rosario M, Berrien-Elliott MM, Wagner JA, Jewell BA, Schappe T, Leong JW, Abdel-Latif S, Schneider SE, Willey S, Neal CC, Yu L, Oh ST, Lee YS, Mulder A, Claas F, Cooper MA, Fehniger TA. Cytokine-induced memory-like natural killer cells exhibit enhanced responses against myeloid leukemia. Sci Transl Med. 2016;8(357):357ra123.

205. Berrien-Elliott MM, Cashen AF, Cubitt CC, Neal CC, Wong P, Wagner JA, Foster M, Schappe T, Desai S, McClain E. Multidimensional analyses of donor memory-like NK cells reveal new associations with response after adoptive immunotherapy for leukemia. Cancer Discov. 2020. https:// doi.org/10.1158/2159-8290.CD-20-0312. 
206. Foltz JA, Berrien-Elliott MM, Neal C, Foster M, McClain E, Schappe T, Desai S, Becker-Hapak M, Cashen AF, Fehniger TA. Cytokine-induced memory-like (ML) NK cells persist for> 2 months following adoptive transfer into leukemia patients with a MHC-compatible hematopoietic cell transplant (HCT). Blood. 2019;134(Supplement_1):1954.

207. Bednarski JJ, Zimmerman C, Cashen AF, Desai S, Foster M, Schappe T, McClain E, Becker-Hapak M, Berrien-Elliott MM, Fehniger TA. Adoptively transferred donor-derived cytokine induced memory-like NK cells persist and induce remission in pediatric patient with relapsed acute myeloid leukemia after hematopoietic cell transplantation. Blood. 2019;134(Supplement_1):3307.

208. Rohner A, Langenkamp U, Siegler U, Kalberer CP, Wodnar-Filipowicz A. Differentiation-promoting drugs up-regulate NKG2D ligand expression and enhance the susceptibility of acute myeloid leukemia cells to natural killer cell-mediated lysis. Leuk Res. 2007;31(10):1393-402.

209. Raneros AB, Puras AM, Rodriguez RM, Colado E, Bernal T, Anguita E, Mogorron AV, Gil AC, Vidal-Castiñeira JR, Márquez-Kisinousky L. Increasing TIMP3 expression by hypomethylating agents diminishes soluble MICA, MICB and ULBP2 shedding in acute myeloid leukemia, facilitating NK cell-mediated immune recognition. Oncotarget. 2017:8(19):31959.

210. Lu X, Ohata K, Kondo Y, Luis Espinoza J, Qi Z, Nakao S. Hydroxyurea upregulates NKG2D ligand expression in myeloid leukemia cells synergistically with valproic acid and potentially enhances susceptibility of leukemic cells to natural killer cell-mediated cytolysis. Cancer Sci. 2010;101(3):609-15.

211. Yun HD, Schirm DK, Felices M, Miller JS, Eckfeldt CE. Dinaciclib enhances natural killer cell cytotoxicity against acute myelogenous leukemia. Blood Adv. 2019;3(16):2448.

212. Diermayr S, Himmelreich $H$, Durovic B, Mathys-Schneeberger A, Siegler U, Langenkamp U, Hofsteenge J, Gratwohl A, Tichelli A, Paluszewska M. NKG2D ligand expression in AML increases in response to HDAC inhibitor valproic acid and contributes to allorecognition by NK-cell lines with single KIR-HLA class I specificities. Blood. 2008;1 11(3):1428-36.

213. Poggi A, Catellani S, Garuti A, Pierri I, Gobbi M, Zocchi MR. Effective in vivo induction of NKG2D ligands in acute myeloid leukaemias by all-trans-retinoic acid or sodium valproate. Leukemia. 2009;23(4):641-8.

214. Le Roy A, Prebet T, Castellano R, Goubard A, Riccardi F, Fauriat C, Granjeaud S, Benyamine A, Castanier C, Orlanducci F. Immunomodulatory drugs exert anti-leukemia effects in acute myeloid leukemia by direct and immunostimulatory activities. Front Immunol. 2018;9:977.

215. Yu FS, Yang JS, Yu CS, Chiang JH, Lu CC, Chung HK, Yu CC, Wu CC, Ho HC, Chung JG. Safrole suppresses murine myelomonocytic leukemia WEHI-3 cells in vivo, and stimulates macrophage phagocytosis and natural killer cell cytotoxicity in leukemic mice. Environ Toxicol. 2013;28(11):601-8.

216. Lin J-J, Lu K-W, Ma Y-S, Tang N-Y, Wu P-P, Wu C-C, Lu H-F, Lin J-G, Chung $J$-G. Alpha-phellandrene, a natural active monoterpene, influences a murine WEHI-3 leukemia model in vivo by enhancing macrophague phagocytosis and natural killer cell activity. Vivo. 2014;28(4):583-8.

217. Lai K-C, Lu H-F, Chen K-B, Hsueh S-C, Chung J-G, Huang W-W, Chen C-C, Shang H-S. Casticin promotes immune responses, enhances macrophage and NK cell activities, and increases survival rates of leukemia BALB/c mice. Am J Chin Med. 2019:47(01):223-36.

218. Shih YL, Shang HS, Chen YL, Hsueh SC, Chou HM, Lu HF, Lee MZ, Hou HT, Chuang YY, Lee MH. Ouabain promotes immune responses in WEHI-3 cells to generate leukemia mice through enhancing phagocytosis and natural killer cell activities in vivo. Environ Toxicol. 2019;34(5):659-65.

219. Lee JY, Park S, Kim DC, Yoon J-H, Shin SH, Min W-S, Kim H-J. A VEGFR-3 antagonist increases IFN- $y$ expression on low functioning NK cells in acute myeloid leukemia. J Clin Immunol. 2013;33(4):826-37.

220. Lee JY, Park S, Min W-S, Kim H-J. Restoration of natural killer cell cytotoxicity by VEGFR-3 inhibition in myelogenous leukemia. Cancer Lett. 2014;354(2):281-9.

221. Otegbeye F, Ojo E, Moreton S, Mackowski N, Lee DA, de Lima M, Wald DN. Inhibiting TGF-beta signaling preserves the function of highly activated, in vitro expanded natural killer cells in AML and colon cancer models. PLoS ONE. 2018;13(1):e0191358.

222. Morgan MA, Büning H, Sauer M, Schambach A. Use of cell and genome modification technologies to generate improved "off-the-shelf" CART and CAR NK Cells. Front Immunol. 1965;2020:11.

223. Suck G, Odendahl M, Nowakowska P, Seidl C, Wels WS, Klingemann HG, Tonn T. NK-92: an 'off-the-shelf therapeutic' for adoptive natural killer cell-based cancer immunotherapy. Cancer Immunol Immunother. 2016;65(4):485-92.

224. Spanholtz J, Preijers F, Tordoir M, Trilsbeek C, Paardekooper J, De Witte T, Schaap N, Dolstra H. Clinical-grade generation of active NK cells from cord blood hematopoietic progenitor cells for immunotherapy using a closed-system culture process. PLoS ONE. 2011;6(6):e20740.

225. Shankar K, Capitini CM, Saha K. Genome engineering of induced pluripotent stem cells to manufacture natural killer cell therapies. Stem cell Res Therapy. 2020;11(1):1-14.

226. Zhang Y, Wallace DL, de Lara CM, Ghattas H, Asquith B, Worth A, Griffin GE, Taylor GP, Tough DF, Beverley PC, Macallan DC. In vivo kinetics of human natural killer cells: the effects of ageing and acute and chronic viral infection. Immunology. 2007;121(2):258-65.

227. Hu Y, Tian Z-G, Zhang C. Chimeric antigen receptor (CAR)-transduced natural killer cells in tumor immunotherapy. Acta Pharmacol Sin. 2018;39(2):167-76.

228. LiY, Hermanson DL, Moriarity BS, Kaufman DS. Human iPSC-derived natural killer cells engineered with chimeric antigen receptors enhance anti-tumor activity. Cell Stem Cell. 2018;23(2):181-92.

229. Pahl JHW, Koch J, Götz J-J, Arnold A, Reusch U, Gantke T, Rajkovic E, Treder M, Cerwenka A. CD16A activation of NK cells promotes NK cell proliferation and memory-like cytotoxicity against cancer cells. Cancer Immunol Res. 2018;6(5):517-27.

230. Cany J, Roeven MWH, Hoogstad-van Evert JS, Hobo W, Maas F, Franco Fernandez R, Blijlevens NMA, van der Velden WJ, Huls G, Jansen JH. Decitabine enhances targeting of AML cells by CD34+ progenitor-derived NK cells in NOD/SCID/LL2Rgnull mice. Blood. 2018:131(2):202-14.

231. Jiang W, Zhang C, Tian Z, Zhang J. hlL-15 gene-modified human natural killer cells (NKL-IL15) augments the anti-human hepatocellular carcinoma effect in vivo. Immunobiology. 2014;219(7):547-53.

\section{Publisher's Note}

Springer Nature remains neutral with regard to jurisdictional claims in published maps and institutional affiliations.

\footnotetext{
Ready to submit your research? Choose BMC and benefit from:

- fast, convenient online submission

- thorough peer review by experienced researchers in your field

- rapid publication on acceptance

- support for research data, including large and complex data types

- gold Open Access which fosters wider collaboration and increased citations

- maximum visibility for your research: over $100 \mathrm{M}$ website views per year
}

At BMC, research is always in progress.

Learn more biomedcentral.com/submissions 